\title{
The bivalve Glycymeris planicostalis as a high-resolution paleoclimate archive for the Rupelian (Early Oligocene) of central Europe
}

\author{
E. O. Walliser ${ }^{1}$, B. R. Schöne ${ }^{1}$, T. Tütken ${ }^{1}$, J. Zirkel ${ }^{1,{ }^{*}}$, K. I. Grimm ${ }^{1}$, and J. Pross ${ }^{2}$ \\ ${ }^{1}$ Institute of Geosciences, University of Mainz, Johann-Joachim-Becher-Weg 21, 55128 Mainz, Germany \\ ${ }^{2}$ Paleoenvironmental Dynamics Group, Institute of Earth Sciences, University of Heidelberg, \\ Im Neuenheimer Feld 234, 69120 Heidelberg, Germany \\ *now at: Institute of Geosciences, University of Frankfurt, Altenhöferallee 1, 60438 Frankfurt am Main, Germany
}

Correspondence to: E. O. Walliser (walliser@uni-mainz.de)

Received: 11 September 2014 - Published in Clim. Past Discuss.: 17 October 2014

Revised: 8 January 2015 - Accepted: 17 March 2015 - Published: 10 April 2015

\begin{abstract}
Current global warming is likely to result in a unipolar glaciated world with unpredictable repercussions on atmospheric and oceanic circulation patterns. These changes are expected to affect seasonal extremes and the year-toyear variability of seasonality. To better constrain the mode and tempo of the anticipated changes, climatologists require ultra-high-resolution proxy data of time intervals in the past, e.g., the Oligocene, during which boundary conditions were similar to those predicted for the near future. In the present paper, we assess whether such information can be obtained from shells of the long-lived bivalve mollusk Glycymeris planicostalis from the late Rupelian of the Mainz Basin, Germany. Our results indicate that the studied shells are pristinely preserved and provide an excellent archive for reconstructing changes of sea surface temperature on seasonal to interannual timescales. Shells of $G$. planicostalis grew uninterruptedly during winter and summer and therefore recorded the full seasonal temperature amplitude that prevailed in the Mainz Basin $\sim 30 \mathrm{Ma}$. Absolute sea surface temperature data were reconstructed from $\delta^{18} \mathrm{O}_{\text {shell }}$ values assuming a $\delta^{18} \mathrm{O}_{\text {water }}$ signature that was extrapolated from coeval sirenian tooth enamel. Reconstructed values range between 12.3 and $22.0^{\circ} \mathrm{C}$ and agree well with previous estimates based on planktonic foraminifera and shark teeth. However, temperatures during seasonal extremes vary greatly on interannual timescales. Mathematically re-sampled (i.e., corrected for uneven number of samples per annual increment) winter and summer tempera-
\end{abstract}

tures averaged over 40 annual increments of three specimens equal $13.6 \pm 0.8$ and $17.3 \pm 1.2^{\circ} \mathrm{C}$, respectively. Such highresolution paleoclimate information can be highly relevant for numerical climate studies aiming to predict possible future climates in a unipolar glaciated or, ultimately, polar-icefree world.

\section{Introduction}

Current $\mathrm{CO}_{2}$-induced global warming is likely to result in a unipolar glaciated world ultimately followed by one without polar ice caps (e.g., Raper and Braithwaite, 2006). In light of these predicted boundary conditions, the climate is expected to change profoundly, particularly at higher latitudes. According to numerical climate models, reduced meridional gradients will lead to substantial changes in atmospheric and oceanic circulation patterns (e.g., Cai and Chu, 1998; Hansen et al., 2004), thereby affecting seasonality as well as the frequency and intensity of decadal climate oscillations (e.g., Marshall et al., 2001; Solomon et al., 2007). In turn, this will alter surface temperature patterns, storm intensities and precipitation rates (Hurrell, 1995; Dai et al., 1997; Barbosa, 2009), all of which present a major challenge to densely populated coastal areas and coastal ecosystems, particularly in Europe (Ottersen et al., 2001; Stenseth et al., 2002).

To date, the mode and tempo of the environmental change anticipated for the near future have remained poorly constrained (e.g., Vellinga and Wood, 2002; Hátún et al., 2005). 
This applies particularly to timescales of human perception, i.e., seasonal extremes and interannual variability. A promising avenue toward a better understanding of the future climate is to investigate the short-term climate variability of time intervals in the past during which boundary conditions were similar to those predicted for the coming millennia. The last time a unipolar glaciated world occurred in Earth history was during the Early Oligocene when atmospheric $\mathrm{CO}_{2}$ levels were slightly higher than today (Zachos et al., 2008) and the paleogeographic configuration on a global scale was at least broadly similar to the present-day situation (Lefebvre et al., 2013). Thus, the Oligocene world can serve as a natural laboratory for studying the possible effects of anthropogenic global warming. As yet, however, the Oligocene has remained a relatively poorly studied epoch of Earth history, which is at least partially attributed to the stratigraphic incompleteness of many Oligocene successions. In particular, shallow-water sequences of Oligocene age are often compromised by unconformities resulting from strong, glacially induced eustatic sea-level fluctuations (e.g., Miller et al., 2005; Pälike et al., 2006).

The epicontinental sedimentary archives from the Oligocene of central Europe, notably the Rhenish triple junction system (e.g., Sissingh, 2003), can play a prime role in elucidating the short-term (i.e., seasonal to interannual) climate dynamics during that time. The significance of Oligocene sediments from the Rhenish triple junction system was first stressed by Beyrich (1854), whose work on strata from the Mainz and Kassel basins ultimately led to the coinage of the term "Oligocene". These shallow marine successions exhibit much higher sedimentation rates and generally contain more macrofossils than their open marine counterparts. Moreover, the shallow water depth and the low water-mass inertia as compared to the open ocean make them particularly sensitive to short-term paleoclimatic and paleoceanographic change. Furthermore, these strata contain well-preserved shells of long-lived bivalves (Glycymeris planicostalis, Lamarck, 1819). Modern Glycymeris spp. have recently been identified as promising tools for ultrahigh-resolution climate reconstructions (Brocas et al., 2013; Royer et al., 2013; Bušelić et al., 2015). This genus occurs worldwide in subtidal settings and lives infaunally in sandy and gravelly sediments (Ansell and Trueman, 1967; Thomas, 1978). Their fossil history dates back to the Aptian (Gillet, 1924; Casey, 1961), and despite some evolutionary innovations acquired during the early Cenozoic, their fundamental bauplan has remained largely unvaried until today (Thomas, 1975).

Bivalve shells serve as reliable recorders of ambient environmental conditions (e.g., Wanamaker et al., 2011). The production of shell material occurs on a periodic basis resulting in the formation of distinct growth lines that separate the growth pattern into time slices of equal duration, so-called growth increments. These growth patterns serve as a calendar which can be used to place each shell portion and each geochemical data point in a precise temporal context. Some bivalve species live for decades to several centuries and can therefore provide uninterrupted records of seasonality such as the genera Glycymeris (Ramsay et al., 2000; Brocas et al., 2013), Arctica (e.g., Ropes, 1985; Butler et al., 2013) and Panopea (e.g., Strom et al., 2004; Black et al., 2008).

In the present study, we have analyzed the ontogenetically young shell portions of three G. planicostalis specimens from the upper Rupelian of the Mainz Basin, SW Germany, with regard to their oxygen isotopic composition in order to assess their potential as "deep-time" archives of paleoseasonality. Such data are currently not available. In particular, we focused on elucidating (i) whether the shells are sufficiently well preserved to permit reconstruction of water temperatures from shell oxygen isotope data; (ii) what the timing and rate of seasonal shell growth of these specimens were; and (iii) how the seasonal $\delta^{18} \mathrm{O}_{\text {shell-derived water tem- }}$ peratures compare to existing temperature proxy data from that region. In order to assess the oxygen isotope composition of the local seawater $\left(\delta^{18} \mathrm{O}_{\text {water }}\right)$ in the Mainz Basin during the Rupelian, we measured the phosphate oxygen isotope composition $\left({ }^{18} \mathrm{O}_{\mathrm{PO}_{4}}\right)$ of the enamel of seven teeth of the sea cow Halitherium schinzii from the same formation as the G. planicostalis shells. The $\delta^{18} \mathrm{O}_{\mathrm{PO}_{4}}$ value has been successfully used as a $\delta^{18} \mathrm{O}_{\text {water }}$ proxy by many authors (e.g., Clementz and Koch, 2001; Clementz et al., 2006; Thewissen et al., 2007; Clementz and Sewall, 2009). Hence, this study lays the groundwork for future ultra-high-resolution paleoclimate reconstructions for the Oligocene.

\section{Material and methods}

\subsection{Study area}

The Mainz Basin is located near the northwestern margin of the Upper Rhine Graben. Its formation dates back to the middle Eocene and is related to the taphrogenesis of the European Cenozoic rift system (Dèzes et al., 2004; Ritzkowski, 2005; Grimm et al., 2011; Fig. 1). Its sedimentary succession, which was mainly deposited in shallow marine and brackish settings, covers a time interval of ca. $20 \mathrm{My}$, from the Lutetian $(\sim 49.5 \mathrm{Ma})$ to the early Burdigalian $(\sim 18.5 \mathrm{Ma})$. During the late Rupelian (i.e., late Early Oligocene; 34.928.4 Ma; Gradstein et al., 2004), central Europe experienced a period of extended marine transgressions due to local tectonic subsidence and eustatic sea level rise. As a consequence, the Mainz Basin became part of a marine strait that extended from the paleo-North Sea basin to the southernmost Upper Rhine Graben (Picot, 2002; Sissingh, 2003; Berger et al., 2005a). A possible southern connection with the western Molasse Basin has been controversially debated (Martini, 1982; Picot, 2002; Berger et al., 2005a, b; Grimm, 2006). 
According to Berger et al. (2005b), marine conditions in the Mainz Basin lasted for about 2.5 My from the sea-level highstands $\mathrm{Ru} 2 / \mathrm{Ru} 3$ ( $32 \mathrm{Ma})$ to Ru3/Ru4 ( 29.5 Ma) of Haq et al. (1988). Nearshore deposits representing that time comprise coarse-grained (sand to gravel) siliciclastics of the Alzey formation (from which the studied fossil material was collected - see below) and the overlaying Stadecken formation. Contemporaneously deposited basinal sediments (pelites) belong to the Bodenheim formation (Grimm et al., 2000; Sissingh, 2003; Berger et al., 2005b). Age control for the marine strata of the Mainz Basin is mainly based on calcareous nanoplankton (Martini and Müller, 1971; Martini, 1982), dinoflagellate cysts (e.g., Pross, 1997) and, to a lesser extent, benthic foraminifera (Grimm, 1998, 2002). With regard to the nanoplankton zonation, the Alzey and Bodenheim formations comprise the upper part of nanoplankton zone NP23 and the lower part of nanoplankton zone NP24 (Grimm, 1994; Pross and Schmiedl, 2002; Berger et al., 2005b).

Paleoenvironmental reconstructions of the Alzey formation are based on palynological and faunal data indicating an overall warm climate comparable to modern subtropical climate zones of the Mediterranean (Grimm et al., 2011). Reconstructed mean annual air temperature in the hinterland fluctuated between $\sim 16$ and $\sim 17^{\circ} \mathrm{C}$, and mean annual precipitation was between 1000 and $1250 \mathrm{~mm}$ per year (Pross et al., 1998, 2000). The Mainz Basin experienced repeated alternations between drier and wetter conditions during the deposition of the Alzey formation, which caused fluctuations in surface water salinity levels (remaining within the range of normal marine conditions) and the episodic formation of water-mass stratifications (Pross, 2001; Pross and Schmiedl, 2002). Temperature estimates of the seawater have been derived from the $\delta^{18} \mathrm{O}$ values of shark teeth and foraminiferal tests. These estimates yielded values of 6.9 to $23.3^{\circ} \mathrm{C}$ for shallow-water settings (Tütken, 2003) and 5.9 to $14.9^{\circ} \mathrm{C}$ for bottom waters (maximum depth: $150 \mathrm{~m}$; Grimm, 1994; Grimm et al., 2011).

\subsection{Material}

The studied shell material was collected by Jürgen Boy during the 1970s and 1980s and has been stored at the Paleontology Collection of the Institute of Geosciences in Mainz. Samples originate from the "Trift" outcrop near Weinheim, the stratotype of the Alzey formation (Grimm et al., 2000; Fig. 1). Additional information about the precise stratigraphic position of the sampled layer is not available. The outcrop is $\sim 8 \mathrm{~m}$ thick and $\sim 40 \mathrm{~m}$ wide; it consists of fossiliferous middle-to-coarse sands and fine gravels. Numerical dating with strontium isotope $\left({ }^{87} \mathrm{Sr} /{ }^{86} \mathrm{Sr}\right)$ stratigraphy of a well-preserved bivalve shell from the outcrop yielded an age of $30.1 \pm 0.1 \mathrm{Ma}$ (Grimm et al., 2003). The outcrop exhibits a highly diverse and fully marine benthic fauna dominated by bivalves, gastropods and scaphopods
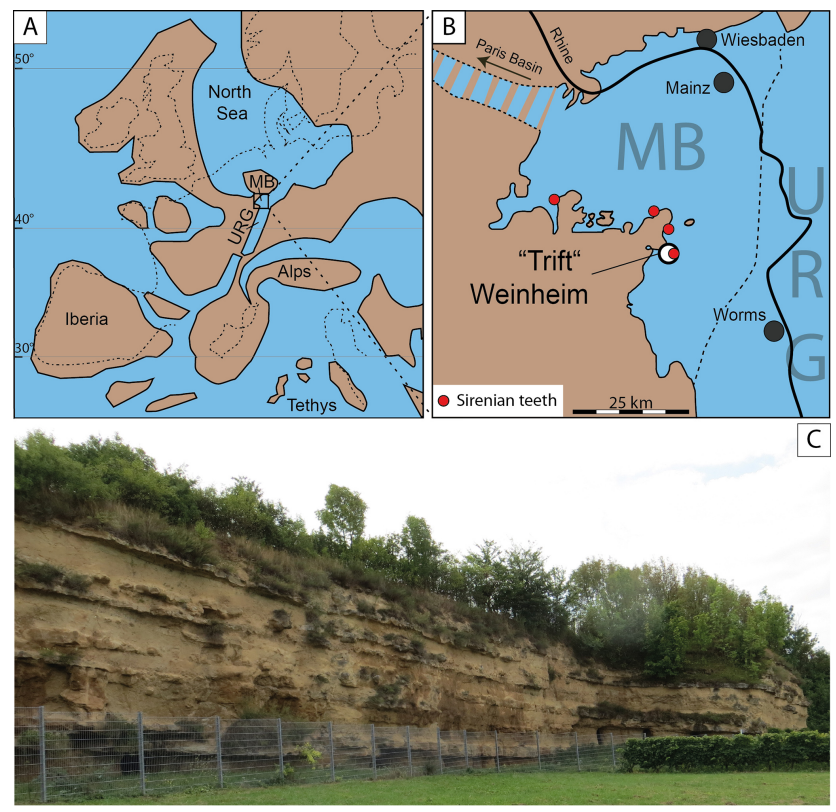

Figure 1. Map showing the paleogeography during the Rupelian stage and the sample locality in the Mainz Basin. (a) Position of the Mainz Basin (MB) in central Europe. URG stands for Upper Rhine Graben. Emerged land areas are shown in brown and marine environments in blue. Modified from Spiegel et al. (2007). (b) Sample locality of the shells (Trift outcrop near Weinheim; white dot) and sea cow teeth (red dots). The presence of a western gateway (dashed area) connecting the Mainz Basin to the Paris Basin is unclear. Dashed line denotes the tectonic boundary between the MB and URG. Modified after Grimm et al. (2011). (c) Photograph of the Trift outcrop near Weinheim, the type locality of the Alzey formation from which the bivalves were collected.

that dwelled in shallow subtidal waters. Furthermore, corals were found, suggesting limited seasonal salinity changes. Water-depth estimates, which are based on sedimentological features (Grimm et al., 2003) and ichnofossils (Schindler et al., 2005), range from $\sim 30$ to $\sim 40 \mathrm{~m}$. The sea cow teeth originated from four localities located along the southwestern paleo-coastline of the Mainz Basin (Fig. 1; Table 1), and were stored at the Paleontology Collection of the Institute of Geosciences and the collection of the Museum of Natural History Mainz/Landessamlung für Naturkunde Rheinland Pfalz.

\subsection{Methods}

From the Glycymeris planicostalis specimens collected at the Trift outcrop, three large valves ( $\sim 8 \mathrm{~cm}$ in height) that visually appeared well-preserved were selected for further investigations. These valves were labeled (MB-Wht-2, MB-Wht-4 and MB-Wht-7), mounted on Plexiglas cubes with GlueTec Multipower plastic welder and coated with WIKO metal epoxy resin to avoid fracture during cross sectioning. From each valve, two ca. $3 \mathrm{~mm}$ thick slabs were cut perpendicular 
Table 1. Enamel $\delta^{18} \mathrm{O}_{\mathrm{PO}_{4}}$ and $\delta^{18} \mathrm{O}_{\mathrm{CO}_{3}}$ values (VSMOW) of the sea cow teeth from the Alzey formation deposits of the Mainz Basin and $\delta^{18} \mathrm{O}_{\text {water values calculated from the sea cow enamel } \delta}{ }^{18} \mathrm{O}_{\mathrm{PO}_{4}}$ values. See text for details.

\begin{tabular}{llccc}
\hline Sample ID & Sample locality & $\delta^{18} \mathrm{O}_{\mathrm{PO}_{4}}[\%$ o $]$ & $\delta^{18} \mathrm{O}_{\mathrm{CO}_{3}}[\%$ o $]$ & $\delta^{18} \mathrm{O}_{\text {water }}[\%$ o $]$ \\
\hline Trai 01-1 & Traisen & 19.36 & 25.79 & -1.01 \\
Trai 01-2 & Traisen & 19.04 & 26.14 & -1.38 \\
Eck 01-1 & Eckelsheim & 19.29 & 26.40 & -1.09 \\
Eck 01-2 & Eckelsheim & 19.74 & 26.40 & -0.57 \\
Wein 01-1 & Weinheim & 19.31 & 26.63 & -1.07 \\
Wein 01-2 & Weinheim & 19.36 & 26.64 & -1.01 \\
PW 2008/5017-LS-2-1 & Alzey-Weinheim & 19.32 & 26.31 & -1.06 \\
PW 2008/5017-LS-2-2 & Alzey-Weinheim & 19.55 & 26.74 & -0.79 \\
PW 2008/5017-LS-1B & Alzey-Weinheim & 20.03 & 27.05 & -0.23 \\
PW 2008/5017-LS-1A & Alzey-Weinheim & 19.35 & 26.40 & -1.02 \\
STS-BE 62-1 & Eckelsheim & 19.07 & 25.98 & -1.35 \\
PW 2005/5042-LS-1 & Wendelsheim & 19.75 & 26.67 & -0.56 \\
Average $\pm 1 \sigma$ & & $19.43 \pm 0.29$ & $26.43 \pm 0.35$ & $-0.9 \pm 0.3$ \\
Min & & 19.04 & 25.79 & -1.38 \\
Max & & 20.03 & 27.05 & -0.23 \\
\hline
\end{tabular}

to the growth lines and along the axis of maximum growth from the umbo to the commissure using a low-speed precision saw (Buehler Isomet 1000; at 200 rpm) equipped with a wafer-thin $(0.4 \mathrm{~mm})$, diamond-coated blade. Both shell slabs were glued to glass slides with the mirroring sides facing up, ground on glass plates $(320,800,1200$ grit $\mathrm{SiC}$ powder) and polished with $1 \mu \mathrm{m} \mathrm{Al}_{2} \mathrm{O}_{3}$ powder. After each preparation step, the samples were ultrasonically rinsed in deionized water.

One polished slab of each specimen was firstly used for diagenetic screening. For this purpose, a set of different methods was employed including cathodoluminescence petrography, Raman spectroscopy and immersion of the shell slabs in Feigl solution. The presence of $\mathrm{Mn}^{2+}$ (> 10-20 ppm) in calcium carbonates produces an orange cathodoluminescence (Machel et al., 1991) and is typically regarded as an indicator of diagenetic neomorphism (Grossman et al., 1996; Flügel, 2004) because biogenic aragonite is non-cathodoluminescent (Major, 1991). Like modern Glycymeris spp., shells of fossil representatives of this genus consisted of aragonite, which is prone to change to calcite during diagenesis. Raman spectroscopy can yield detailed and spatially highly resolved information on the type of polymorphs of $\mathrm{CaCO}_{3}$. The Feigl test can likewise distinguish between aragonite and calcite (Feigl, 1958). Feigl solution stains aragonite black and calcite pale grey. After diagenesis screening, the shell slabs were ground and polished again, and prepared for sclerochronological studies and subsequent scanning electron microscopic (SEM) analyses. For this purpose, polished cross sections were immersed in Mutvei's solution for 40 min under constant stirring at $37-40^{\circ} \mathrm{C}$ (Schöne et al., 2005a). After the staining process, the samples were gently rinsed in deionized water, air dried and then photographed with a digital camera (Canon EOS 600D) mounted to a binocular microscope
(Wild Heerbrugg M8). Growth increments were counted and their width measured with the image processing software Panopea ( ${ }^{\odot}$ Peinl and Schöne). Subsequently, samples were sputter-coated with a $2 \mathrm{~nm}$ thick gold layer and viewed under a scanning electron microscope (LOT Quantum Design Phenom Pro, second generation) in order to describe the prevailing microstructures and identify possible neomorphic minerals that may have formed during diagenesis (Fig. 2).

The other polished slab of each specimen was used for the analysis of oxygen isotope values $\left(\delta^{18} \mathrm{O}_{\text {shell }}\right)$. Prior to the analysis, the outer ca. 0.5 to $1 \mathrm{~mm}$ thick chalky rim of the shell surfaces was physically removed (Fig. 2a-c). Then, 675 individual carbonate powder samples were micro-milled from the outer shell layer (ventral margin) of the three specimens (316, 193 and 166 samples from specimens MB-Wht2, MB-Wht-4 and MB-Wht-7, respectively) using a Rexim Minimo dental drill mounted to a stereo microscope and equipped with a cylindrical, diamond-coated bit $(1 \mathrm{~mm}$ diameter; Komet/Gebr. Brasseler GmbH \& Co. KG, model no. 835104 010). Sampling was performed in the ontogenetically youngest part of the shells. Individual milling steps contoured the shell growth patterns and measured between 100 and $200 \mu \mathrm{m}$ in width. Carbonate powder samples weighing between 50 and $120 \mu \mathrm{g}$ were reacted with $100 \%$ phosphoric acid in He-flushed borosilicate exetainers at $72^{\circ} \mathrm{C}$. The resulting $\mathrm{CO}_{2}$ was measured with a GasBench II-coupled Thermo Finnigan MAT 253 gas source isotope ratio mass spectrometer in continuous flow mode at the Institute of Geosciences of the University of Mainz. Oxygen isotope values are reported in $\delta$ notation and given as parts per mill $(\% o)$. Data were calibrated against a NBS-19 calibrated IVA Carrara marble $\left(\delta^{18} \mathrm{O}=-1.91 \%\right)$. On average, replicated internal precision $(1 \sigma)$ and accuracy $(1 \sigma)$ were better than $0.05 \%$, respectively. 

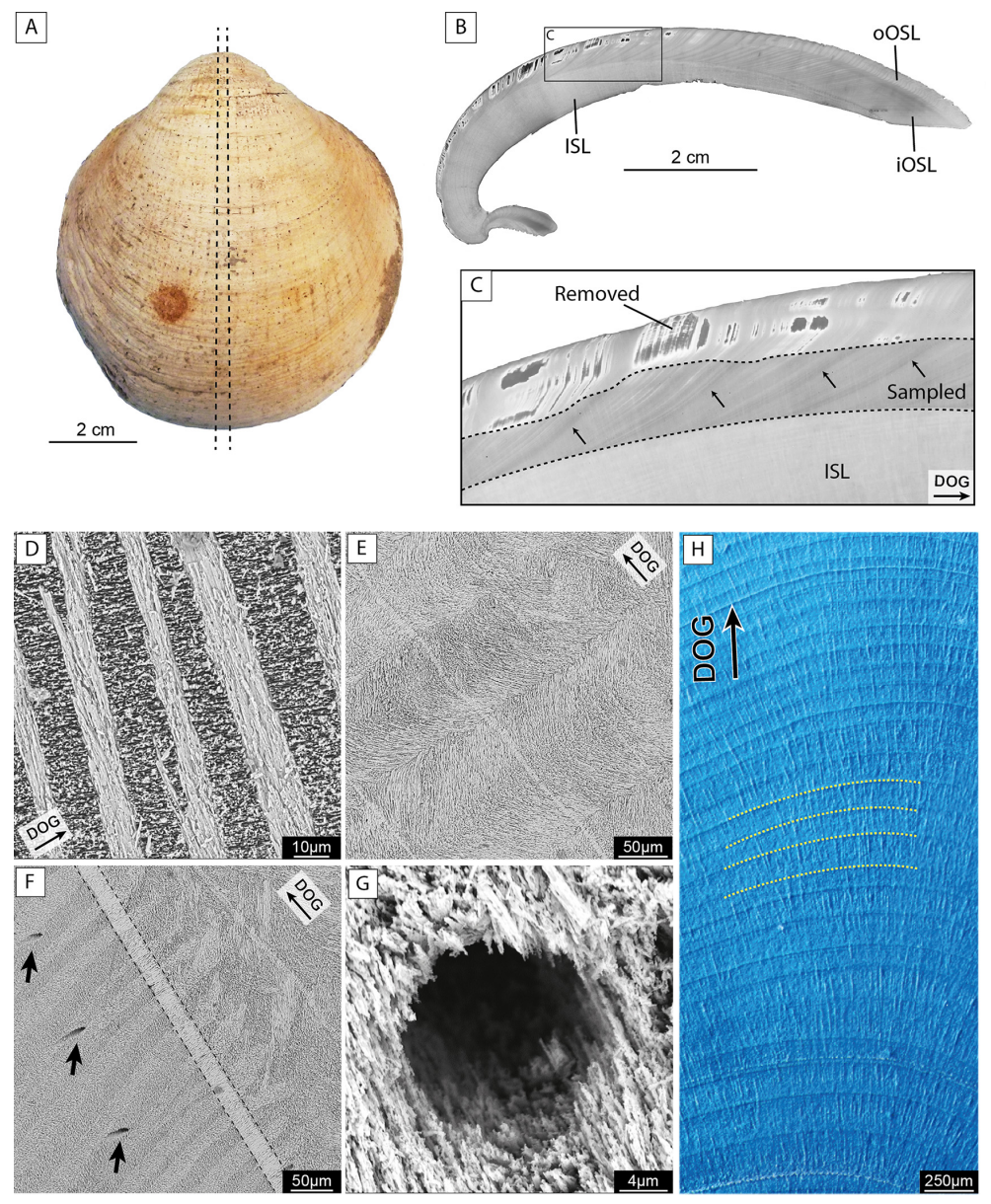

Figure 2. Macroscopic and microscopic views of the studied shell material (Glycymeris planicostalis) from the Early Oligocene of the Mainz Basin. (a) Left valve. Dotted lines show the cutting axis. (b) Outer and inner portions of the outer shell layer (oOSL, iOSL) as well as the inner shell layer (ISL) are clearly visible in the umbo-ventral margin cross section (dotted line in A) of specimen EOW-MB-Wht-7. (c) Carbonate powder was collected from the outer shell layer after removing the outer chalky shell portions. Arrows point to annual growth lines. (d-g) SEM images show the extraordinary preservation state of the studied shell material. Primary microstructures are still present. (d) Outer crossed-lamellar layer, (e) inner complex crossed-lamellar layer and (f) transition zone between outer and inner shell layer (dotted lines). Arrows point to tubule openings. (g) Detailed view of a tubule. The lack of diagenetic fillings inside the cavity further supports the absence of any significant diagenetic overprint. (h) Distinct growth lines (yellow dotted lines) are visible in the hinge plate of Mutvei-stained cross sections. DOG stands for direction of growth.

If the bivalves formed their shell in oxygen isotopic equilibrium with the ambient water, the $\delta^{18} \mathrm{O}_{\text {shell }}$ values could provide information on water temperature during growth (Epstein et al., 1953). For aragonitic shells, the paleothermometry equation of Grossman and $\mathrm{Ku}(1986)$ with a scale correction of $-0.27 \%$ o (see Dettman et al., 1999) is typically employed:

$T_{\delta^{18} \mathrm{O}}\left({ }^{\circ} \mathrm{C}\right)=20.60-4.34 \cdot\left(\delta^{18} \mathrm{O}_{\text {shell }}-\left(\delta^{18} \mathrm{O}_{\text {water }}-0.27\right)\right)$,

where $\delta^{18} \mathrm{O}_{\text {shell }}$ is measured relative to VPDB and $\delta^{18} \mathrm{O}_{\text {water }}$ relative to VSMOW. Computing reliable temperatures from $\delta^{18} \mathrm{O}_{\text {shell }}$ values also requires knowledge of the $\delta^{18} \mathrm{O}_{\text {water }}$ value during shell formation. This value was reconstructed from $\delta^{18} \mathrm{O}_{\mathrm{PO}_{4}}$ values of tooth enamel of sea cows, i.e., ho- moeothermic marine mammals, from the same stratigraphic level. The average $T_{\delta^{18} \mathrm{O}}$ error was calculated by combining the average precision errors of the mass spectrometric analyses of bivalve shells and sirenian teeth (error propagation method). This resulted in an average $T_{\delta^{18} \mathrm{O}}$ error of $\pm 0.4^{\circ} \mathrm{C}$. An additional source of uncertainty is represented by the standard deviation of the reconstructed average $\delta^{18} \mathrm{O}_{\text {water }}$ values $( \pm 0.3 \%$ ) . The integration of both values results in a combined temperature error of $\pm 1.3^{\circ} \mathrm{C}$.

\subsection{Sea cow teeth}

The oxygen isotope composition of tooth enamel from marine vertebrates can provide information on the $\delta^{18} \mathrm{O}_{\text {water }}$ value of ambient seawater (e.g., Lécuyer et al., 1996; 
Clementz and Koch, 2001; Clementz et al., 2006; Clementz and Sewall, 2009). Therefore, we measured the phosphate oxygen isotope composition $\left(\delta^{18} \mathrm{O}_{\mathrm{PO}_{4}}\right)$ of the enamel from seven sirenian teeth of Halitherium schinzii recovered from the deposits of the Alzey formation.

The surface of the teeth was physically cleaned and then sampled with a handheld dental drill. Five teeth which were large enough were sampled twice: once from the top and once from the bottom of the crown. A fraction of each enamel powder sample was then treated with $2 \% \mathrm{NaOCl}$ and $0.18 \mathrm{~mL}$ of 0.1 molar acetic acid to remove organics and potential diagenetic carbonates, respectively. Subsequently, ca. $4 \mathrm{mg}$ of each pretreated sample was converted into silver phosphate $\left(\mathrm{Ag}_{3} \mathrm{PO}_{4}\right)$ following the method of O'Neil et al. (1994) with modifications of Dettman et al. (2001) and Tütken et al. (2006). Triplicates of $500 \mu \mathrm{g}$ of each $\mathrm{Ag}_{3} \mathrm{PO}_{4}$ sample were analyzed with a Thermo Fisher Delta Plus XL mass spectrometer coupled to a thermal conversion elemental analyzer (TC/EA) at the University of Tübingen, Germany. Measured values were normalized to calibrated inhouse standards, Tu-1 and Tu-2 (Vennemann et al., 2002) and reported in $\delta$ notation versus VSMOW. Replicate $(n=6)$ analyses of NBS 120c (pretreated as the samples) yielded a $\delta^{18} \mathrm{O}_{\mathrm{PO}_{4}}$ value of $21.6 \pm 0.13 \%$, which agrees well with the value of $21.7 \%$ reported by Lécuyer et al. (1993) and subsequently confirmed by many other laboratories (summarized in the appendix of Chenery et al., 2010). The $\delta^{18} \mathrm{O}_{\mathrm{PO}_{4}}$ values of the $H$. schinzii teeth of the Mainz Basin were converted into $\delta^{18} \mathrm{O}_{\text {water }}$ values using the equation determined for modern sirenians by Tütken (2003):

$\delta^{18} \mathrm{O}_{\text {water }}=\frac{\delta^{18} \mathrm{O}_{\mathrm{PO}_{4}-20.23}}{0.86}$,

where $\delta^{18} \mathrm{O}_{\text {water }}$ and $\delta^{18} \mathrm{O}_{\mathrm{PO}_{4}}$ are given relative to VSMOW. We used the equation of Tütken (2003) instead of the one proposed by Lécuyer et al. (1996) because the calibration of Eq. (2) is based on more sea cow specimens and covers a range of measured ambient $\delta^{18} \mathrm{O}_{\text {water }}$ values 3 times larger. However, $\delta^{18} \mathrm{O}_{\text {water }}$ values reconstructed using both equations yielded similar values that are statistically invariant (Tütken, 2003: $-0.9 \pm 0.3 \%$; Lécuyer et al., 1996: $-0.6 \pm$ ca. $0.8 \%$ o).

In order to assess the possibility of diagenetic alteration of the enamel oxygen isotope composition, the carbonate $\left(\delta^{18} \mathrm{O}_{\mathrm{CO}_{3}}\right)$ and the phosphate $\left(\delta^{18} \mathrm{O}_{\mathrm{PO}_{4}}\right)$ group of the enamel were plotted against each other and compared to a compilation of $\delta^{18} \mathrm{O}_{\mathrm{CO}_{3}}$ vs. $\delta^{18} \mathrm{O}_{\mathrm{PO}_{4}}$ pairs from extant mammals published by Pellegrini et al. (2011). The $\delta^{18} \mathrm{O}_{\mathrm{CO}_{3}}$ values were determined in the remaining fraction of the pretreated H. schinzii enamel powders. About $800 \mu \mathrm{g}$ of each enamel powder sample was analyzed with a Thermo Finnigan MAT 253 gas source isotope ratio mass spectrometer in continuous flow mode equipped with a GasBench II at the University of Mainz. The $\delta^{18} \mathrm{O}_{\mathrm{CO}_{3}}$ values were measured against VPDB and normalized to a NBS-18 and NBS-19 calibrated
Laas marble $(-5.21 \%$; replicated precision, $1 \sigma$, better than $0.1 \%$ ). Afterward, the results were converted to the SMOW scale using the equation of Coplen et al. (1983):

$\delta^{18} \mathrm{O}_{\mathrm{SMOW}}=1.03091 \cdot \delta^{18} \mathrm{O}_{\mathrm{PDB}}+30.91$.

\subsection{Mathematical re-sampling of intra-annual isotope data}

In bivalves, shell growth rate declines during ontogeny resulting in increasingly narrow annual growth increments with increasing lifespan (Jones and Quitmyer, 1996). Since the isotope samples were taken at approximately equidistant intervals (100 to $200 \mu \mathrm{m}$ ), the number of samples per year decreases towards the ventral margin, and the time represented by each carbonate sample (time-averaging) increases in ontogenetically older shell portions. To compensate for that bias and make the isotope samples from different ontogenetic years comparable to each other, the number of $\delta^{18} \mathrm{O}_{\text {shell }} \mathrm{val}$ ues per year was mathematically equalized by a re-sampling technique similar to that described in Schöne et al. (2004) and Hallmann et al. (2011). Following previous work (e.g., Schöne and Fiebig, 2008; Wanamaker et al., 2011), we fitted the isotope data of each annual increment with a sevenpoint cubic spline using Analyseries 1.1 software (Paillard et al., 1996) and re-sampled each intra-annual curve so that the same number of isotope values were available for each annual increment, i.e., seven $\delta^{18} \mathrm{O}_{\text {shell }}$ ' values. This re-sampling method slightly deviated from previous approaches (Schöne et al., 2004; Hallmann et al., 2011) because it was impossible to determine seasonal growth curves from microgrowth patterns. Hence, the $\delta^{18} \mathrm{O}_{\text {shell }}$ ' values within a given year most likely represented different amounts of time, but the first, second, third, etc. $\delta^{18} \mathrm{O}_{\text {shell' }}$ values of different years represented the same amounts of time.

\section{Results}

\subsection{Preservation of material}

According to a set of different diagenesis screening tests outlined above, the studied shells of Glycymeris planicostalis from the Rupelian of the Mainz Basin consist of aragonite and were remarkably well preserved. This even applies to the chalky rims of the shells, i.e., the shell portions that were only pale blue stained by Mutvei's solution and lost almost all organics during taphonomy. Orange cathodoluminescence was only emitted from a very few isolated spots, i.e., cracks containing neomorphic mineral phases. Most other portions of the shells were dark blue to non-luminescent. Moreover, both reflected light microscope and electron microscope analyses revealed the same shell microstructures that occur in modern representatives of this genus, i.e., crossed-lamellar structures (Fig. 2d-f). Alternately, the first-order lamellae appear dark and bright because the higher-order lamellae are arranged in a fence-like manner and stand perpendicular to 


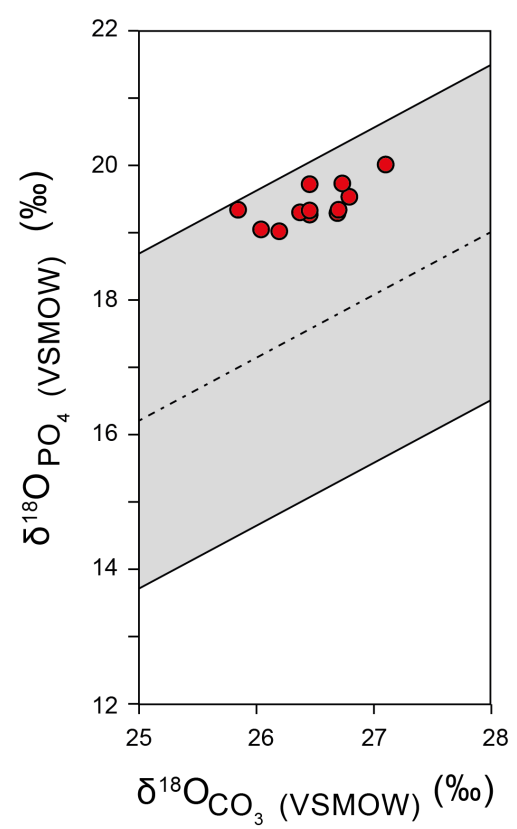

Figure 3. Cross plot of mammal tooth enamel $\delta^{18} \mathrm{O}_{\mathrm{PO}_{4}}$ and $\delta^{18} \mathrm{O}_{\mathrm{CO}_{3}}$ pairs (dashed line is the average; grey area shows $95 \%$ prediction intervals) compiled by Pellegrini et al. (2011) with respective data from the seven Oligocene sirenian teeth of the present study (solid red circles). Sea cow isotope data plot within the $95 \%$ prediction intervals suggesting that diagenesis has not affected the isotope composition of the phosphate group.

each other (compare Füllenbach et al., 2014). Furthermore, both shell layers are perforated by numerous hollow microtubuli (Fig. 2g), especially in the juvenile portion of the shells. On rare occasions, these tubuli (ca. $10 \mu \mathrm{m}$ in diameter) are filled with pyrite crystals or iron oxides.

Like the bivalves, the studied sirenian teeth are well preserved (Fig. 3). The $\delta^{18} \mathrm{O}_{\mathrm{CO}_{3}}$ vs. $\delta^{18} \mathrm{O}_{\mathrm{PO}_{4}}$ pairs of the seven specimens plot well within the $95 \%$ prediction intervals of modern and other well-preserved fossil mammal bioapatite data compiled by Pellegrini et al. (2011; Table 1; Fig. 3). Digenetic alteration of tooth enamel would in the first place have affected the carbonate-bound oxygen (Iacumin et al., 1996) and resulted in $\delta^{18} \mathrm{O}_{\mathrm{CO}_{3}}$ vs. $\delta^{18} \mathrm{O}_{\mathrm{PO}_{4}}$ pairs plotted farther away from the regression line depicted in Pellegrini et al. (2011). Given the excellent preservation, $\delta^{18} \mathrm{O}_{\text {water }}$ values were computed from $\delta^{18} \mathrm{O}_{\mathrm{PO}_{4}}$ values of the enamel using Eq. (2). On average, the $\delta^{18} \mathrm{O}_{\text {water }}$ value of the ambient seawater was $-0.9 \pm 0.3 \%$ o $(1 \sigma)$.

\subsection{Bivalve sclerochronology: $\delta^{18} \mathrm{O}_{\text {shell }}$ and reconstructed water temperatures}

The studied fossil G. planicostalis specimens show distinct growth lines in the ventral margin and the hinge plate of Mutvei-stained cross sections (Fig. 2h). These lines were previously identified as periodic annual features (Berthou et al.,
1986; Royer et al., 2013; Bušelić et al., 2014) separating the growth pattern in annual time slices, i.e., annual growth increments. The annual growth lines are more distinctly developed and hence easier to discern in the hinge plate than in the ventral margin. Based on annual increment counts, it was possible to determine the ontogenetic ages of the specimens. Specimens MB-Wht-2, MB-Wht-4 and MB-Wht-7 reached life spans of 77, 84 and 67 years, respectively.

Oxygen isotope curves of all three specimens exhibit distinct seasonal oscillations $(16,14$ and 10 cycles in specimens MB-Wht-2, 4, and 7, respectively) with the annual growth lines occurring shortly after the most negative $\delta^{18} \mathrm{O}_{\text {shell }}$ values of each cycle (Fig. 4; see Supplement). In other words, the full seasonal amplitudes are preserved in the shells including winter and summer values. The annual growth line formation occurred in late summer/early fall.

The shells grew faster during the first half of the year than after summer. This is well reflected in the seasonal temperature curve based on the averaged $\delta^{18} \mathrm{O}_{\text {shell }}$ ' values of all 40 measured annual increments (Fig. 5). There are more data points in shell portions formed during spring than in shell portions formed during fall (Fig. 5). Accordingly, the reconstructed temperature curve is right skewed.

The average annual $\delta^{18} \mathrm{O}_{\text {shell }}$ values and seasonal $\delta^{18} \mathrm{O}_{\text {shell }}$ ranges are fairly similar among the three studied specimens (Table 2). Seasonal extremes fluctuate between $-1.48 \%$ o (summer value) and $0.75 \%$ (winter value) in specimen MBWht-2, between -1.16 and $0.67 \%$ in specimen MB-Wht4 and between -1.19 and $0.60 \%$ in specimen MB-Wht7. Using the reconstructed $\delta^{18} \mathrm{O}_{\text {water }}$ value, this translates into total temperature $\left(T_{\delta 180}\right)$ ranges of $9.7,7.6$ and $7.8^{\circ} \mathrm{C}$ in specimens MB-Wht-2, MB-Wht-4 and MB-Wht-7, respectively. Taking the resampled values of the 40 seasonal cycles of all three specimens, the average annual temperature is $15.4 \pm 0.7^{\circ} \mathrm{C}(1 \sigma)$, and the seasonal temperature range equals $3.7^{\circ} \mathrm{C}$ with average minimum (winter) values of $13.6 \pm 0.8^{\circ} \mathrm{C}(1 \sigma)$ and average maximum (summer) values of $17.3 \pm 1.2^{\circ} \mathrm{C}(1 \sigma)$. It is worth noting that the seasonal amplitudes vary through time. In some years, the seasonal $T_{\delta^{18} \mathrm{O}}$ range was less than $2{ }^{\circ} \mathrm{C}$ (Fig. 4).

\section{Discussion}

As demonstrated by this study, shells of Glycymeris planicostalis provide an excellent archive for reconstructing climate dynamics - in particular changes of sea surface temperature - during the Oligocene on subseasonal to interannual timescales. Shells of the studied species grew during both the coldest and warmest periods of the year and therefore contain information on the full seasonal temperature amplitude over a coherent time interval of several years that prevailed in the Mainz Basin $~ 30$ Ma. Furthermore, the shells are pristinely preserved and their $\delta^{18} \mathrm{O}_{\text {shell }}$ values potentially reflect changes of ambient water temperature. 
Table 2. Oxygen isotope values $\left(\delta^{18} \mathrm{O}\right.$ vs. VPDB) of the three Glycymeris planicostalis shells analyzed in this study. The table lists seasonal extremes $\left(\delta^{18} \mathrm{O}_{\min }\right.$ and $\left.\delta^{18} \mathrm{O}_{\max }\right)$ as well as average summer $\left(\delta^{18} \mathrm{O}_{\text {summer }}^{\prime}\right.$; re-sampled values; explanation see text) and winter extremes values $\left(\delta^{18} \mathrm{O}_{\text {winter }}^{\prime}\right)$.

\begin{tabular}{lccccc}
\hline Sample ID & $\delta^{18} \mathrm{O}_{\min }[\%$ o $]$ & $\delta^{18} \mathrm{O}_{\text {summer }}^{\prime} \pm 1 \sigma[\%$ ] & $\delta^{18} \mathrm{O}_{\max }[\%$ o $]$ & $\delta^{18} \mathrm{O}_{\text {winter }}^{\prime} \pm 1 \sigma[\%$ o $]$ & $\delta^{18} \mathrm{O}_{\text {mean }} \pm \sigma[\%$ o \\
\hline MB-Wht-2 & -1.48 & $-0.66 \pm 0.21$ & 0.75 & $0.38 \pm 0.23$ & $-0.12 \pm 0.13$ \\
MB-Wht-4 & -1.16 & $-0.40 \pm 0.31$ & 0.67 & $0.28 \pm 0.14$ & $-0.03 \pm 0.13$ \\
MB-Wht-7 & -1.19 & $-0.61 \pm 0.23$ & 0.60 & $0.24 \pm 0.19$ & $-0.20 \pm 0.16$ \\
\hline
\end{tabular}

\subsection{Preservation}

According to diagenetic screening, the studied G. planicostalis shells are well preserved. The shells consist of pristine aragonite. Furthermore, SEM analysis revealed original delicate shell microstructures including the typical skeletal feature of Glycymeris spp., i.e., microtubuli. These cylindrical cavities perforate the inner and outer shell layers and are filled with organics during the lifetime of the animal (e.g., Waller, 1980; Crippa, 2013). The diagenetic loss of organic material leaves behind hollow cavities that could potentially be filled with neomorphic mineral phases. However, the microtubuli of the studied specimens were typically hollow and only rarely contained pyrite. Pyrite crystals can even occur in shells of living bivalves and are possibly related to the bacterial degradation of organic matter (Clark and Lutz, 1980).

In fact, the recovery of pristinely preserved fossil Glycymeris spp. has been reported from many other localities and geological time intervals (e.g., Tsuboi and Hirata, 1935; Crippa, 2013). Since Glycymeris spp. dwell in sandy to fine gravelly habitats, shells of this genus are usually embedded in coarse grained and highly porous sediments. In such types of host rock and stratigraphic age, one would not expect aragonitic shell preservation, particularly if the burial depth is shallow (few tens of meters) and the sediment is still unconsolidated as is the case with the weakly cemented sandstones of the Alzey formation. Under surface conditions, aragonite is metastable and slowly turns into the more stable polymorph of $\mathrm{CaCO}_{3}$, i.e., calcite (Boettcher and Wyllie, 1967). This conversion into calcite can be expedited when a fluid is present (Putnis and Putnis, 2007) and when temperature is increased (Dasgupta, 1963). The resistance of Glycymeris shells against diagenetic alteration likely resulted from low organic content and the dense crossed-lamellar microstructure (Taylor and Layman, 1972).

\subsection{Timing and rate of shell growth}

Pristine preservation is a major prerequisite for the reconstruction of environmental variables from geochemical properties of the shells including ambient water temperature from

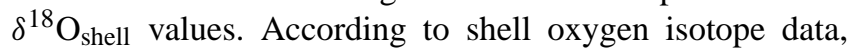
the studied shells grew during winter and summer. Similar findings on shell growth during seasonal extremes were recently reported for modern Glycymeris bimaculata from
Croatia (Bušelić et al., 2014). The only difference is that the Oligocene shells formed annual growth lines in late summer/early fall, whereas the period of extremely slow or no shell growth in specimens from Croatia occurs during spring. On the contrary, modern G. glycymeris from the North Atlantic form annual growth breaks in winter (Berthou et al., 1986; Royer et al., 2013). These findings suggest that the timing and rate of shell growth can vary greatly among different species of the same genus and most likely even among specimens of the same species living in different localities (e.g., Ansell, 1968; Jones and Quitmyer, 1996).

A number of explanations have been proposed to explain the reason for periodic cessation of shell growth. Temperature stress seems to limit shell growth in many bivalves. Above and below a taxon-specific water temperature range, biomineralization ceases and results in the formation of winter or summer growth lines (Jones and Quitmyer, 1996) or even both (Schöne et al., 2002). For example, Mercenaria mercenaria stops shell growth above 31 and below $9^{\circ} \mathrm{C}$ (Ansell, 1968). Following this explanation, modern G. glycymeris from the North Atlantic forms winter lines when temperatures fall below the tolerance limit of this species, as suggested by Royer et al. (2013). In some taxa, annual growth line formation can also be linked to the reproductive cycle. For example, Phacosoma japonicum from Japan not only forms winter lines but also slows down shell growth regularly during June and July, i.e., during the peak spawning phase (Sato, 1995). Instead of biomineralizing shell, the energy is then allocated to the formation of eggs and sperm. Spawning breaks may be limited to species lacking specific tissues for energy (lipids) storage. Modern G. glycymeris from the North Atlantic, for example, belongs to this group of bivalves and reportedly spawns once or twice per year between spring and fall (Galap et al., 1997). In the Mediterranean Sea, G. nummaria spawns in July and August, followed by a sudden decrease of the condition index in late summer/fall (Crnčević et al., 2013). However, it has remained unresolved whether modern Glycymeris spp. can only form shell during periods of sexual inactivity. Existing studies on seasonal shell growth of this genus were based on juvenile specimens or juvenile portions of adult specimens (Peharda et al., 2012; Bušelić et al., 2014; Royer et al., 2013). Therefore, it is difficult to draw conclusions on how the reproductive cycle affects seasonal growth in (modern) Gly- 

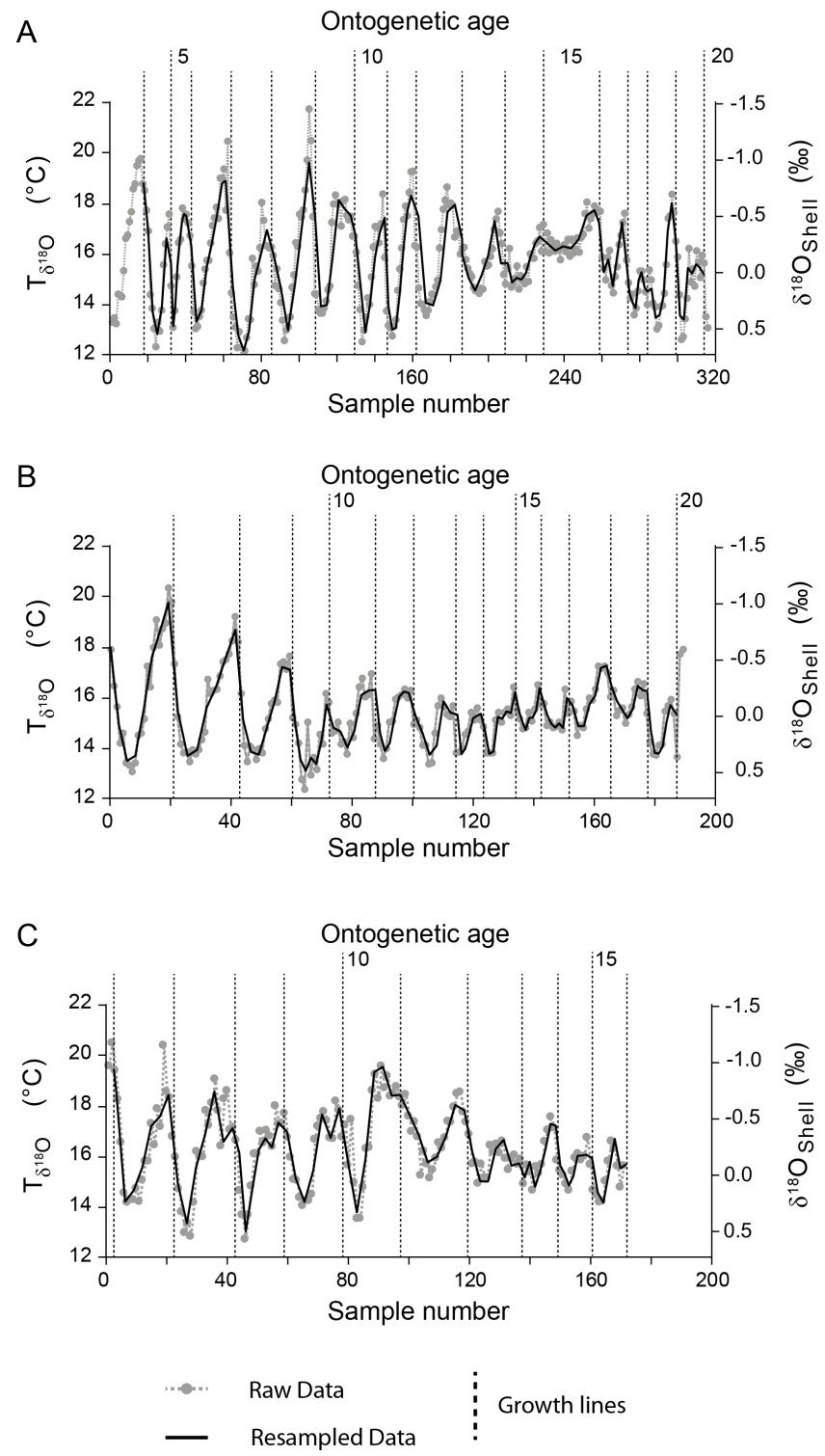

Figure 4. Raw (grey) and re-sampled (black) $\delta^{18} \mathrm{O}_{\text {shell values for }}$ each of the three Glycymeris planicostalis shells analyzed in this study ((a) = MB-Wht-2; (b) = MB-Wht-4; (c) = MB-Wht-7). Vertical dotted bars represent annual growth lines. Temperatures were calculated using Eq. (2) with a $\delta^{18} \mathrm{O}_{\text {water value reconstructed from }}$ $\delta^{18} \mathrm{O}_{\mathrm{PO}_{4}}$ values of sea cow tooth enamel (see text for description).

cymeris spp. It is not possible to determine whether growth line formation of G. planicostalis was governed by reproduction or other environmental factors. At the least, the annual growth lines in the studied specimens from the Oligocene are unrelated to seasonal temperature extremes because the lines do not fall together with the most negative and positive oxygen-isotope-derived water temperatures (Fig. 4).

Shell growth rates of the studied bivalves from the Early Oligocene of the Mainz Basin also varied during the main growing season. For example, shell production was faster

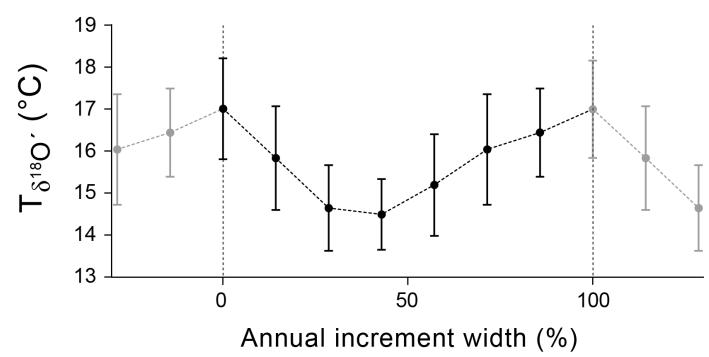

Figure 5. Average seasonal temperature changes (black dots, $\pm 1 \sigma$ ) based on mathematically re-sampled shell oxygen isotope values ( $\delta^{18} \mathrm{O}_{\text {shell }}$ ' values; see text for explanation) of 40 annual increments measured in three specimens of Glycymeris planicostalis. Note that the resultant temperature curve is not symmetric as one would expect, but right skewed, indicating slower shell growth occurred during fall and winter than during the remainder of the year. In other words, more shell material was deposited during spring and summer than during fall and winter.

during spring and summer than during fall and winter. This finding has implications for geochemical sampling strategies. In order to obtain reliable information on the actual seasonal temperature spread, a higher sampling resolution has to be applied in slow-growing shell portions.

\subsection{Temperatures of the Mainz Basin during the Rupelian}

Only few temperature estimates of the Mainz Basin and adjacent regions during the Rupelian are currently available. For example, sediments of the Alzey formation contain diverse warm-water fauna including marine fish, mammals and crocodiles as well as terrestrial turtles. Based on this fossil assemblage, subtropical climate conditions - similar to the modern southeastern Mediterranean - were inferred for the Mainz Basin (Grimm et al., 2003, 2011). Furthermore, macroflora and palynological data from the Bodenheim formation yielded winter and summer air temperatures of 7.110.2 and $25.7-28.1^{\circ} \mathrm{C}$, respectively (Pross et al., 1998; Pross et al., 2000). These estimates compare well with those obtained from fossil floras of other contemporaneous localities in central Europe (Mosbrugger et al., 2005; Erdei et al., 2012).

Knowledge on water temperatures of the Mainz Basin comes from oxygen isotope compositions of biogenic skeletons. Tütken (2003) reported $\delta^{18} \mathrm{O}_{\mathrm{PO}_{4}}$ values of shark teeth that correspond to absolute temperatures between 6.9 and $23.3^{\circ} \mathrm{C}$ (temperatures recalculated assuming a $\delta^{18} \mathrm{O}_{\text {water }}$ value of $-0.9 \%$; Table 3 ), using the thermometry equation of Longinelli and Nuti (1973). Grimm (1994) reported oxygen isotope data of planktonic and benthic foraminifera that can be converted into absolute temperatures using the paleothermometry equation by Anderson and Arthur (1983) and a $\delta^{18} \mathrm{O}_{\text {water value of }}-0.9 \%$. Based on this calculation, sea 
Table 3. Dentine and enamel $\delta^{18} \mathrm{O}_{\mathrm{PO}_{4}}$ values (VSMOW) of shark teeth recovered from the Early Oligocene deposits of the Mainz Basin (Tütken, 2003). Values have been converted to temperature $\left(T \delta^{18} \mathrm{O}_{\mathrm{PO}_{4}}\right)$ using the paleothermometry equation by Longinelli and Nuti (1973) assuming $\delta^{18} \mathrm{O}_{\text {water }}=-0.9 \%$.

\begin{tabular}{llcc}
\hline Sample ID & Genus & $\delta^{18} \mathrm{O}_{\mathrm{PO}_{4}}[\% o]$ & $\mathrm{T} \delta{ }^{18} \mathrm{O}_{\mathrm{PO}_{4}}\left[{ }^{\circ} \mathrm{C}\right]$ \\
\hline FD HAI MB 2 & Carcharias sp. & 22.9 & 9.1 \\
FZ HAI MB 2 & Carcharias sp. & 22.8 & 9.5 \\
FZ HAI MB 3 & Carcharias sp. & 19.6 & 23.3 \\
FD HAI MB 4 & Carcharias sp. & 21.0 & 17.2 \\
FZ HAI MB 4 & Carcharias sp. & 21.5 & 15.1 \\
FZ HAI MB 8 & Carcharias sp. & 20.1 & 21.1 \\
FZ HAI MB 9 & Carcharias sp. & 21.0 & 17.2 \\
FZ HAI MB 10 & Carcharias sp. & 23.4 & 6.9 \\
Average $\pm 1 \sigma$ & & $21.5 \pm 1.3$ & $14.9 \pm 5.9$ \\
Min & & 19.6 & 6.9 \\
Max & & 23.4 & 23.3 \\
\hline
\end{tabular}

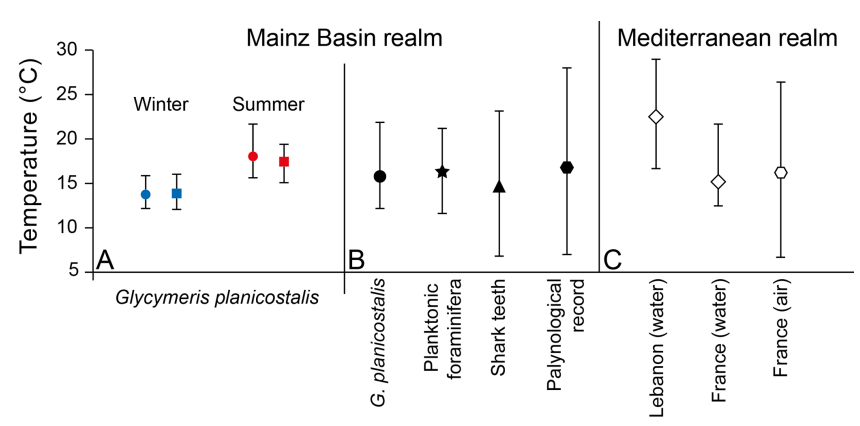

Figure 6. Seasonal temperature ranges and averages. (a) Comparison between raw (circles) and mathematically re-sampled (squares) summer (red) and winter (blue) temperature data based on shell oxygen isotope data of three fossil Glycymeris planicostalis shells. Whereas mathematical re-sampling did not greatly affect average values and winter ranges, the summer temperature range of resampled data is truncated. (b) Comparison of the reconstructed tem-

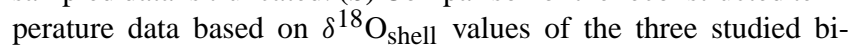
valve shells (solid black circle) and previously published temperature data based on planktonic foraminifera (Grimm, 1994), shark teeth (Tütken, 2003) and palynological associations (Pross et al., 2000). (c) Seawater temperatures off Lebanon and southern France at $35 \mathrm{~m}$ depth (Abboud-Abi Saab et al., 2004) and air temperatures in southern France (Global Historical Climatology Network (GHCN) Monthly Dataset; Lawrimore et al., 2011).

surface temperatures of the Mainz Basin fluctuated between 11.7 and $21.3^{\circ} \mathrm{C}$ (Table 4), whereas bottom water (up to $150 \mathrm{~m}$ depth; Grimm et al., 2011) temperatures were as cold as 5.9 to $14.9{ }^{\circ} \mathrm{C}$ during the Rupelian. Similar surface water temperatures were reconstructed from bivalve shells in the present study $\left(12.3\right.$ and $22.0^{\circ} \mathrm{C}$ ), although the lowest temperatures are $\sim 5^{\circ} \mathrm{C}$ higher than those obtained from shark teeth (Fig. 6). Leaving aside the fact that it is rather unlikely that the studied bivalves, sharks and foraminifera lived during the exact same time interval, a direct comparison of temperature extremes derived from the different marine archives seems problematic for a variety of reasons:

(i) The temporal resolution provided by foraminifera is much higher than that of bivalves. Foraminiferan tests can grow within a few weeks (Bé et al., 1981). Thus, each specimen recorded environmental conditions during a very short time interval of the year. In contrast, each sample taken from the bivalve shells represents, on average, about 2 weeks to 1 month worth of growth. Foraminifera samples analyzed so far may not necessarily have grown when the most extreme seasonal temperatures occurred. Accordingly, actual winter temperatures may have been slightly colder and summers slightly warmer than suggested by the $\delta^{18} \mathrm{O}$ values of foraminifera.

(ii) Seasonal temperature extremes given by sharks may not represent the actual temperatures of where the bivalves lived. Being highly mobile, nektonic organisms, the sharks may have foraged temporarily in the shallowest waters near the coast and at other times dived to the very bottom of the sea. In addition to vertical movements, they may have traveled large distances such as modern sharks (e.g., Domeier and Nasby-Lucas, 2008). The lowest temperatures recorded by sharks may thus represent conditions below the thermocline or settings much further north instead of winter temperatures in the Mainz Basin. In turn, those teeth that provided temperature estimates of $22^{\circ} \mathrm{C}$ may actually have been formed while the animals lived in warmer waters farther south or near the coast.

(iii) Actual sea surface temperatures during both winter and summer may have been underestimated by the planktonic foraminifera (and sharks while they resided in shallowest, coastal waters) because the assumed average $\delta^{18} \mathrm{O}_{\text {water }}$ value did not reflect the actual isotope signature of the water. Planktonic foraminifera lived in the upper few meters of the water column in a narrow, shallow epicontinental sea. In such a habitat, seasonally varying riverine fresh- 
water influx, precipitation and evaporation rates likely resulted in seasonal changes of the $\delta^{18} \mathrm{O}_{\text {water }}$ value. Increased evaporation during summer may have shifted the $\delta^{18} \mathrm{O}_{\text {water }}$ value toward more positive values resulting in lower-thanactual reconstructed water temperatures near the sea surface. In contrast, higher precipitation rates during winter may have shifted the $\delta^{18} \mathrm{O}_{\text {water }}$ value toward more negative values so that the oxygen-isotope-derived temperatures appeared colder than they actually were. Indications for a seasonally varying $\delta^{18} \mathrm{O}_{\text {water }}$ value come, to some extent, from sirenian teeth. Like their extant relatives, sea cows lived in the upper 10 meters of the ocean and near the coast (Louise Chilvers et al., 2004). Thus, they have recorded the isotope signature of the near-coastal surface water in which the planktonic foraminifera (Globigerina sp.) lived. Reconstructed $\delta^{18} \mathrm{O}_{\text {water }}$ values fluctuated between -0.2 and $-1.4 \%$. If the latter value reflects conditions during winter and the former during summer, actual seasonal temperatures in the upper few meters of the Mainz Basin reconstructed from foraminifera would range between ca. 11 and $27^{\circ} \mathrm{C}$.

(iv) Bivalve shell-based temperature estimates cannot be compared directly to those of planktonic foraminifera even if the fluctuating $\delta^{18} \mathrm{O}_{\text {water values in the upper few meters of }}$ the ocean are precisely known. At ca. 30-40 m water depth, bivalves likely experienced a smaller seasonal temperature range than organisms in the upper few meters of the sea.

The benthic faunal associations of the Mainz Basin have been interpreted as reflecting paleoclimate conditions similar to those of the modern southeastern Mediterranean Sea (Grimm et al., 2003, 2011). However, temperature estimates derived from G. planicostalis shells suggest lower water temperatures. According to hydrographical studies from coastal regions in the northwestern Mediterranean (France) and southeastern Mediterranean (Lebanon), the temperature in 30 to $40 \mathrm{~m}$ water depth is still influenced by surface conditions (Abboud-Abi Saab et al., 2004). At $35 \mathrm{~m}$ water depth, the temperatures off Lebanon ranged between 16.9 and $29.1^{\circ} \mathrm{C}$ with an annual average of $22.5 \pm 4.1{ }^{\circ} \mathrm{C}(1 \sigma)$, whereas the coastal waters off France ranged between 12.3 and $21.8^{\circ} \mathrm{C}$ with an annual average of $15.2 \pm 2.2^{\circ} \mathrm{C}(1 \sigma)$. Temperatures recorded by $G$. planicostalis lie well within these ranges, which would suggest that water temperatures were more similar to regions in the northwestern Mediterranean than those in subtropical areas. However, the mean annual precipitation in the area of Marseille (Mediterranean coast of southern France) equals $751 \pm 172 \mathrm{~mm}$ (Harris et al., 2014), which is considerably lower than $1000-1250 \mathrm{~mm} \mathrm{a}^{-1}$ reconstructed precipitation rates for the hinterland of the Mainz Basin (Pross et al., 1998, 2000). A possible explanation for the high precipitation rates in central Europe during the Oligocene has been provided by Pross and Schmiedl (2002). The deposition of the Alzey formation and its basinal counterpart, the Bodenheim formation, took place during sea-level highstands, which could have increased the moisture concentration in the atmosphere and thus intensified rainfalls. Such linkage be- tween sea level rise and precipitation has recently been postulated for the early Holocene intensification of AustralianIndonesian monsoon rainfall (Griffiths et al., 2009).

\subsection{Advantages of using shells of Glycymeris planicostalis for reconstruction of Oligocene climate conditions}

The studied specimens of $G$. planicostalis offer a number of advantages over existing marine paleoclimate archives. As sessile organisms, bivalves record the water properties at a specific locality and depth throughout their lifetimes. Since their shells grew almost year-round, each isotope sample can be assigned to a particular season. If preservation permits, daily microgrowth increments can be employed to temporally contextualize the seasonal shell growth to the nearest week or so (e.g., Schöne et al., 2005b). Such an internal calendar is missing in foraminifera.

The studied G. planicostalis specimens lived for several decades and recorded seasonal temperature changes over the course of many consecutive years. This is a clear advantage over other climate archives that only provide very short temporal snapshots of unknown timing within the year such as foraminifera or shark teeth, or over a few consecutive years, such as fish otoliths. Analogously to bivalve shells, they form growth lines, and their oxygen isotope composition can be used for seasonal paleotemperature reconstructions, for example, at the Eocene-Oligocene boundary (Ivany et al., 2000). Although fish otoliths are very common components of marine nektonic microfossil assemblages, their reduced size makes them difficult to sample, and analyses of their chemical composition usually cover only short time intervals.

Long proxy records offer the possibility to examine the variability of winter and summer temperatures over the course of several years. Future studies should generate $\delta^{18} \mathrm{O}_{\text {shell }}$ time series of $G$. planicostalis that are long enough to permit spectral analyses. These data should then be combined with numerical climate models for that time. Furthermore, $\delta^{18} \mathrm{O}_{\text {shell }}$ chronologies should also be compared to increment widths in order to identify potential influences of temperature on shell growth rates.

The $\delta^{18} \mathrm{O}_{\text {water }}$ value at $30-40 \mathrm{~m}$ water depth was most probably much less variable than near the sea surface. Seasonal changes in freshwater influx into the Mainz Basin likely did not have any significant effect on the isotope signature of the water in which the bivalves lived. In fact, modern G. glycymeris from the North Atlantic is most prolific in water with stable salinity of 34-35 PSU (Rombouts et al., 2012). If the same preference is true for the Oligocene relatives of this genus, water temperatures can be reconstructed with smaller error bars from oxygen isotope values of the bivalve shells than from skeletal hard parts of nektonic and planktonic organisms. Evidently, absolute temperature estimates from $\delta^{18} \mathrm{O}$ values require knowledge of the oxygen 
Table 4. Oxygen isotope values ( $\delta^{18} \mathrm{O}$ vs. VPDB) of foraminiferal tests from the Bodenheim formation (Kriegsfeld 5 and Bodenheim 65 well) reported by Grimm (1994). $\delta^{18} \mathrm{O}_{\mathrm{Glob}}$ is Globigerina sp. (planktonic foraminifera); $\delta^{18} \mathrm{O}_{\mathrm{Bol}}$ is Bolivina sp. (benthonic foraminifera). Values have been converted to temperature $\left(T \delta^{18} \mathrm{O}_{\mathrm{Glob}}, T \delta^{18} \mathrm{O}_{\mathrm{Bol}}\right)$ using the equation by Anderson and Arthur $(1983)$ assuming $\delta^{18} \mathrm{O}_{\mathrm{w}}=-0.9 \%$.

\begin{tabular}{ccc|ccc}
\hline & Kriegsfeld 5 & \multicolumn{3}{|c}{ Bodenheim 65 } \\
Depth [m] & $\delta^{18} \mathrm{O}_{\mathrm{Glob}}[\%$ ] & $T \delta^{18} \mathrm{O}_{\mathrm{Glob}}\left[{ }^{\circ} \mathrm{C}\right]$ & Depth [m] & $\delta^{18} \mathrm{O}_{\mathrm{Bol}}[\%$ \% & $T \delta^{18} \mathrm{O}_{\mathrm{Bol}}\left[{ }^{\circ} \mathrm{C}\right]$ \\
\hline 15 & -1.8 & 18.7 & 21.5 & 1.5 & 5.9 \\
23 & -2.4 & 21.3 & 70 & -0.9 & 14.9 \\
25 & -0.1 & 11.7 & 80 & 1.0 & 7.6 \\
28 & -1.3 & 16.5 & 85 & 1.1 & 7.3 \\
30 & -2.0 & 19.5 & 90 & 0.7 & 8.7 \\
32 & -0.7 & 14.1 & 95 & -0.03 & 11.4 \\
34 & -0.8 & 14.5 & 99 & 0.7 & 8.7 \\
Average $\pm 1 \sigma$ & $2.75 \pm 0.81$ & $16.6 \pm 3.4$ & Average & $0.6 \pm 0.8$ & $9.5 \pm 2.9$ \\
Min & -2.4 & 11.7 & Min & -0.9 & 5.9 \\
Max & -0.1 & 21.3 & Max & 1.5 & 14.9 \\
\hline
\end{tabular}

isotope composition of the ambient water, which is rarely available for fossil environments. In the present study, the

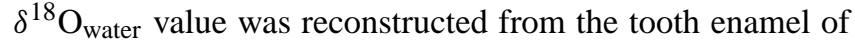
sea cows from the same stratigraphic level. Although the bivalves and the sea cows did most certainly not live during the exact same time and the sphere of action of the sea cows was the upper 10 meters of the ocean, the average $\delta^{18} \mathrm{O}_{\mathrm{PO}_{4}}$ value of the sirenian teeth serves as a reasonable estimate of the Rupelian $\delta^{18} \mathrm{O}_{\text {water value }}(-0.9 \%$ ) of the Mainz Basin. A similar value $(-1 \%$ ) was also assumed by Grimm (1994). For comparison, the $\delta^{18} \mathrm{O}_{\text {water }}$ of the open ocean was $-0.5 \%$ o at that time (Lear et al., 2000). To test the temperature estimates obtained from $\delta^{18} \mathrm{O}_{\text {shell }}$ values and circumvent uncertainties related to the precise $\delta^{18} \mathrm{O}_{\text {water }}$ signature during shell formation, future studies should explore other potential temperature proxies such as $\mathrm{Sr} / \mathrm{Ca}$ and $\Delta_{47}$ values (Eagle et al., 2013).

\section{Summary and conclusions}

Shells of Glycymeris planicostalis serve as excellent recorders of sea surface temperatures in the Mainz Basin during the Rupelian stage. Since the shells were preserved as pristine aragonite, the $\delta^{18} \mathrm{O}_{\text {shell }}$ values can be used to reconstruct ambient water temperature. The $\delta^{18} \mathrm{O}_{\text {water value }}$ for the temperature calculation was reconstructed using tooth enamel $\delta^{18} \mathrm{O}_{\mathrm{PO}_{4}}$ values of the sea cow Halitherium schinzii from the same strata. Although the exact oxygen isotope signature of the water is not known, it is highly likely to assume

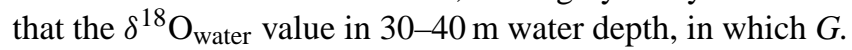
planicostalis lived, remained largely invariant through time. Attributed to its notable longevity, shells of this species can be used to study seasonal temperature changes over several consecutive years, even up to decades. As shown in the present study, summer and winter temperatures varied greatly from year to year. As yet, such data are hardly available from any other paleoclimate archive of the Oligocene.
Such information can be highly relevant for numerical climate studies aiming to predict possible future climates in a unipolar glaciated or polar-ice-free world.

\section{The Supplement related to this article is available online at doi:10.5194/cp-11-653-2015-supplement.}

Acknowledgements. Two anonymous reviewers and Donna Surge kindly provided comments that helped to further improve the manuscript. We gratefully acknowledge the assistance of Christoph Füllenbach, Hilmar A. Holland and Soraya Marali during shell preparation and SEM work. We also thank Thomas Schindler for his comments and for providing some of the sirenian teeth. Furthermore, we thank Michael Maus for his help with isotope analysis. This study has been made possible by a German Research Foundation (DFG) grant to B. R. Schöne (SCHO 793/11-1) and J. Pross (PR 651/14-1).

Edited by: C. Barbante

\section{References}

Abboud-Abi Saab, M., Romano, J.-C., Bensoussan, N., and Fakhri, M.: Suivis temporels comparés de la structure thermique d'eaux côtières libanaises (Batroun) et françaises (Marseille) entre juin 1999 et octobre 2002, C. R. Geosci., 336, 1379-1390, 2004 (in French).

Anderson, T. F. and Arthur, M. A.: Stable isotopes of oxygen and carbon and their application to sedimentologic and paleoenvironmental problems, SEPM Short Course, 10, 1-151, 1983.

Ansell, A. D.: The rate of growth of the hard clam Mercenaria mercenaria (L) throughout the geogrpahical range, J. Cons. Perm. Int. Explor. Mer, 31, 364-409, 1968.

Ansell, A. D. and Trueman, E. R.: Observations on burrowing in Glycymeris glycymeris (L.) (Bivalvia, Arcacea), J. Exp. Mar. Bio. Ecol., 1, 65-75, 1967. 
Barbosa, S. M.: Decadal variability in Europe's seasons, EGU General Assembly Conference, 19-24 April 2009, Vienna, Austria EGU2009-5332-2, 2009.

Bé, A. W. H., Caron, D. A., and Anderson, O. R.: Effects of feeding frequency on life processes of the planktonic foraminifer Globigerinoides sacculifer in laboratory culture, J. Mar. Biol. Assoc. UK., 61, 257-277, 1981.

Berger, J.-P., Reichenbacher, B., Becker, D., Grimm, M. C., Grimm, K. I., Picot, L., Storni, A., Pirkenseer, C., Derer, C., and Schaefer, A.: Paleogeography of the Upper Rhine Graben (URG) and the Swiss Molasse Basin (SMB) from Eocene to Pliocene, Int. J. Earth Sci., 94, 697-710, 2005a.

Berger, J.-P., Reichenbacher, B., Becker, D., Grimm, M. C., Grimm, K. I., Picot, L., Storni, A., Pirkenseer, C., and Schaefer, A.: Eocene-Pliocene time scale and stratigraphy of the Upper Rhine Graben (URG) and the Swiss Molasse Basin (SMB), Int. J. Earth Sci., 94, 711-731, 2005b.

Berthou, P., Blanchard, M., Noel, P., and Vergnaud-Grazzini, C.: The analysis of stable isotopes of the shell applied to the determination of the age of four bivalves of the "Normano-Breton" gulf, Western Channel, International Counil for the Exploration of the Sea, Shellfish Commitee, Copenhagen, Denmark, Annual Report, 1986/K:16, 1-13, 1986.

Beyrich, E.: Über die Stellung der hessischen Tertiärbildungen, Bericht über die zur Bekanntmachung geeigneten Verhandlungen der Königlich Preußischen Akademie der Wissenschaften zu Berlin, Germany, 640-666, 1854 (in German).

Black, B. A., Gillespie, D. C., MacLellan, S. E., and Hand, C. M.: Establishing highly accurate production-age data using the treering technique of crossdating: a case study for Pacific geoduck (Panopea abrupta), Can. J. Fish. Aquat. Sci., 65, 2572-2578, 2008.

Boettcher, A. L. and Wyllie, P. J.: Revision of the calcite-aragonite transition, with the location of a triple point between calcite I, calcite II and aragonite, Nature, 213, 792-793, 1967.

Brocas, W. M., Reynolds, D. J., Butler, P. G., Richardson, C. A., Scourse, J. D., Ridgway, I. D., and Ramsay, K.: The dog cockle, Glycymeris glycymeris (L.), a new annually-resolved sclerochronological archive for the Irish Sea, Palaeogeogr. Palaeocl., 373, 133-140, 2013.

Bušelić, I., Peharda, M., Reynolds, D. J., Butler, P. G., González, A. R., Ezgeta-Balić, D., Vilibić, I., Grbec, B., Hollyman, P., and Richardson, C. A.: Glycymeris bimaculata (Poli, 1795) - A new sclerochronological archive for the Mediterranean?, J. Sea Res., 95, 139-148, 2015.

Butler, P. G., Wanamaker, A. D., Scourse, J. D., Richardson, C. A., and Reynolds, D. J.: Variability of marine climate on the North Icelandic Shelf in a 1357-year proxy archive based on growth increments in the bivalve Arctica islandica, Palaeogeogr. Palaeocl., 373, 141-151, 2013.

Cai, W. and Chu, P. C.: Oceanic responses to gradual transitions of equator-to-pole, Q. J. Roy. Meteor. Soc., 124, 2817-2828, 1998.

Casey, R.: The stratigraphycal palaeontology of the Lower Greensand, Palaeontology, 3, 487-621, 1961.

Chenery, C., Müldner, G., Evans, J., Eckardt, H., and Lewis, M.: Strontium and stable isotope evidence for diet and mobility in Roman Gloucester, UK, J. Archaeol. Sci., 37, 150-163, 2010.

Clark, G. R. and Lutz, R. A.: Pyritization in the shells of living bivalves, Geology, 8, 268-271, 1980.
Clementz, M. T. and Koch, P. L.: Differentiating aquatic mammal habitat and foraging ecology with stable isotopes in tooth enamel, Oecologia, 129, 461-472, 2001.

Clementz, M. T. and Sewall, J. O.: Latitudinal gradients in greenhouse seawater $\delta^{18} \mathrm{O}$ : evidence from Eocene sirenian tooth enamel, Science, 332, 455-458, 2009.

Clementz, M. T., Goswami, A., Gingerich, P. D., and Koch, P. L.: Isotopic records from early whales and sea cows?: contrasting patterns of ecological transition, J. Vertebr. Paleontol., 26, 355370, 2006.

Coplen, T. B., Kendall, C., and Hopple, J.: Comparison of stable isotope reference samples, Nature, 302, 236-238, 1983.

Crippa, G.: The shell ultrastructure of the genus Glycymeris DA COSTA, 1778: a comparison between fossil and recent specimens, Riv. Ital. Paleontol. e S., 119, 387-399, 2013.

Crnčević, M., Peharda, M., Ezgeta-Balić, D., and Pećarević, M.: Reproductivecycle of Glycymeris nummaria (Mollusca: Bivalvia) from Mali Ston Bay, Adriatic Sea, Croatia, Sci. Mar., 77, 293300, 2013.

Dai, A., Fung, I. Y., and Del Genio, A. D.: Surface observed global land precipitation variations during 1900-88, J. Climate, 10, 2943-2962, 1997.

Dasgupta, D. R.: The oriented transformation of aragonite into calcite, Miner. Mag., 33, 924-928, 1963.

Dettman, D. L., Reische, A. K., and Lohmann, K. C.: Controls on the stable isotope composition of seasonal growth bands in aragonitic fresh-water bivalves (unionidae), Geochim. Cosmochim. Ac., 63, 1049-1057, 1999.

Dettman, D. L., Kohn, M. J., Quade, J., Ryerson, F. J., Ojha, T. P., and Hamidullah, S.: Seasonal stable isotope evidence for a strong Asian monsoon throughout the past 10.7 m.y., Geology, 29, 3134, 2001.

Dèzes, P., Schmid, S. M., and Ziegler, P. A.: Evolution of the European Cenozoic Rift System: interaction of the Alpine and Pyrenean orogens with their foreland lithosphere, Tectonophysics, 389, 1-33, 2004.

Domeier, M. and Nasby-Lucas, N.: Migration patterns of white sharks Carcharodon carcharias tagged at Guadalupe Island, Mexico, and identification of an eastern Pacific shared offshore foraging area, Mar. Ecol. Prog. Ser., 370, 221-237, 2008.

Eagle, R. A., Eiler, J. M., Tripati, A. K., Ries, J. B., Freitas, P. S., Hiebenthal, C., Wanamaker Jr., A. D., Taviani, M., Elliot, M., Marenssi, S., Nakamura, K., Ramirez, P., and Roy, K.: The influence of temperature and seawater carbonate saturation state on ${ }^{13} \mathrm{C}-{ }^{18} \mathrm{O}$ bond ordering in bivalve mollusks, Biogeosciences, 10, 4591-4606, doi:10.5194/bg-10-4591-2013, 2013.

Epstein, S., Buchsbaum, R., Lowenstam, H., and Urey, H.: Revisited carbonate-water isotopic temperature scale, B. Am. Meteorol. Soc., 64, 1315-1326, 1953.

Erdei, B., Utescher, T., Hably, L., Tamás, J., Roth-Nebelsick, A., and Grein, M.: Early Oligocene continental climate of the Palaeogene Basin (Hungary and Slovenia) and the surrounding area, Turk. J. Earth Sci., 21, 153-186, 2012.

Feigl, F. (Ed.): Spot tests in inorganic analysis. Fifth enlarged and revisited english edition, Elsevier Pub. Co., Amsterdam, Netherland, 600 pp., 1958.

Flügel, E. (Ed.): Microfacies of carbonate rocks: analysis, interpretation and application, Springer, Berlin, Germany, 984 pp., 2004 
Füllenbach, C. S., Schöne, B. R., and Branscheid, R.: Microstructures in shells of the freshwater gastropod Viviparus viviparus: A potential sensor for temperature change?, Acta Biomater., 1, 3911-3921, 2014.

Galap, C., Leboulenger, F., and Grillot, J.-P.: Seasonal variations in biochemical constituents during the reproductive cycle of the female dog cockle Glycymeris glycymeris, Mar. Biol., 129, 625634, 1997.

Gillet, S.: Études sur les Lamellibranches néocomiens, Mem. S. Geo. F., 1, 1-324, 1924 (in French).

Gradstein, F. M., Ogg, J. G., and Smith, A. G.: A geologic time scale 2004, Cambridge University Press, Cambridge, United Kingdom and New York, NY, USA, 589 pp., 2004.

Griffiths, M. L., Drysdale, R. N., Gagan, M. K., Zhao, J.-X., Ayliffe, L. K., Hellstrom, J. C., Hantoro, W. S., Frisia, S., Feng, Y. -x., Cartwright, I., Pierre, E. St., Fischer, M. J., and Suwargadi, B. W.: Increasing Australian-Indonesian monsoon rainfall linked to early Holocene sea-level rise, Nat. Geosci., 2, 636-639, 2009.

Grimm, K. I.: Paläoökologie, Paläogeographie und Stratigraphie im Mainzer Becken, im Oberrheingraben, in der Hessischen Senke und in der Leipziger Bucht während des Mittleren Rupeltons (Fischschiefer/Rupelium/Unteroligozän), Mitteilungen Pollichia, 81, 7-193, 1994 (in German).

Grimm, K. I.: Correlation of Rupelian coastal and basin facies in the Mainz Basin (Oligocene, Germany), N. Jb. Geol. Paläont. Mitt., 3, 146-156, 1998.

Grimm, K. I.: Foraminiferal zonation of early Oligocene deposits (Selztal Group, Latdorfian, Rupelian) in the Mainz Basin, Germany, J. Micropalaeontol., 21, 67-74, 2002.

Grimm, K. I.: Meeresverbindungen im Rupelium Mitteleuropas - Paläobiogeographische Untersuchungen anhand von Foraminiferen, Geologisches Jahrbuch Hessen, 133, 19-27, 2006 (in German).

Grimm, K. I., Grimm, M. C., and Schindler, T.: Lithostratigraphische Gliederung im Rupelium/Chattium des Mainzer Beckens, Deutschland., N. Jb. Geol. Paläont. Abh., 218, 343-397, 2000 (in German).

Grimm, K. I., Grimm, M. C., Neuffer, F. O., and Lutz, H.: Die fossilen Wirbellosendes Mainzer Tertiärbeckens Teil 1-1 Geologischer Führer durch das Mainzer Tertiärbecken, Mainzer Naturwissenschaftliches Archiv - Beiheft, 26, 1-158, 2003 (in German).

Grimm, K. I., Grimm, M., Radtke, G., Kadolsky, D., Schäfer, P., Franzen, J. L., Schindler, T., and Hottenrott Martin: Mainzer Becken, in: Stratigraphie von Deutschland IX, Tertiär, Teil 1, Deutsche Stratigraphische Kommission (Eds.) - Schriftenreihe der Deutschen Gesellschaft für Geowissenschaften, 75, 133-209, 2011 (in German).

Grossman, E. L. and Ku, T.-L.: Oxygen and carbon isotope fractionation in biogenic aragonite: temperature effects, Chem. Geol., 59, 59-74, 1986.

Grossman, E. L., Mii, H.-Zhang, C., and Yancey, T. E.: Chemical variation in Pennsylvanian brachiopod shells - diagenetic, taxonomic, microstructural, and seasonal effects, J. Sed., 66, 10111022, 1996.

Hallmann, N., Schöne, B. R., Irvine, G. V, Burchell, M., Cokelet, E. D., and Hilton, M. R.: An improved understanding of the Alaska Coastal Current: The application of a bivalve growth-temperature model to reconstruct freshwater-influenced paleoenvironments, Palaios, 26, 346-363, 2011.
Hansen, B., Østerhus, S., Quadfasel, D., and Turrel, W.: Already the Day After Tomorrow?, Science, 305, 953-954, 2004.

Haq, B. U., Hardenbol, J., and Vail, P. R.: Mesozoic and Cenozoic chronostratigraphy and cycles of Sea-Level change, in: Sea-level changes: an integrated approach, edited by: Wilgus, C. K., Hasting, B. S., Posamentier, H., Van Wagoner, J., Ross, C. K., and Kendall, C. G. S. C, SEPM Spec. Publ., 42, 71-108, 1988.

Harris, I., Jones, P. D., Osborn, T. J., and Lister, D. H.: Updated high-resolution grids of monthly climatic observations - the CRU TS3.10 Dataset, Int. J. Climatol., 34, 623-642, 2014.

Hátún, H., Sandø, A. B., Drange, H., Hansen, B., and Valdimarsson, H.: Influence of the Atlantic subpolar gyre on the thermohaline circulation, Science, 309, 1841-1844, 2005.

Hurrell, J. W.: Decadal trends in the North Atlantic Oscillation: regional temperatures and precipitation, Science, 269, 676-679, 1995.

Iacumin, P., Bocherens, H., Mariotti, A., and Longinelli, A.: Oxygen isotope analyses of co-existing carbonate and phosphate in biogenic apatite: a way to monitor diagenetic alteration of bone phosphate?, Earth Planet. Sci. Lett., 142, 1-6, 1996.

Ivany, L. C., Patterson, W. P., and Lohmann, K. C.: Cooler winters as a possible cause of mass extinctions at the Eocene/Oligocene boundary, Nature, 407, 887-890, 2000.

Jones, D. S. and Quitmyer, I. R.: Marking time with bivalve shells: oxygen isotopes and season of annual increment formation, Palaios, 11, 340-346, 1996.

Lamarck, J. P. B. A.: Histoire naturelle des animaux sans vertèbres, présentant les caractères généraux et particuliers de ces animaux, leur distribution, leurs classes, leurs familles, leurs genres, et la citation des principales espèces qui s'y rapportent; précédée d'une introduction offrant la détermination des caractères essentiels de l'animal, sa distinction du végétal et des autres corps naturels, enfin, l'exposition des principes fondamentaux de la zoologie, Tome sixième, 1re partie, Deterville and Verdière, Paris, France, 1-343, 1819.

Lawrimore, J. H. , Menne, M. J., Gleason, B. E., Williams, C. N., Wuertz, D. B., Vose, R. S., and Rennie, J.: An overview of the Global Historical Climatology Network 25 monthly mean temperature data set, version 3, J. Geophys. Res., 116, D19121, doi:10.1029/2011JD016187, 2011.

Lear, C. H., Elderfield, H., and Wilson, P. A.: Cenozoic deep-sea temperatures and global ice volumes from $\mathrm{Mg} / \mathrm{Ca}$ in benthic foraminiferal Calcite, Science, 287, 269-272, 2000.

Lécuyer, C., Grandjean, P., O’Neil, J. R., Cappetta, H., and Martineau, F.: Thermal excursions in the ocean at the Cretaceous - Tertiary boundary (northern Morocco): $\delta^{18} \mathrm{O}$ record of phosphatic fish debris, Palaeogeogr. Palaeocl., 105, 235-243, 1993.

Lécuyer, C., Grandjean, P., Paris, F., Robardet, M., and Robineau, D.: Deciphering "temperature" and "salinity" from biogenic phosphates: the $\delta^{18} \mathrm{O}$ of coexisting fishes and mammals of the Middle Miocene sea of western France, Palaeogeogr. Palaeocl., 126, 61-74, 1996.

Lefebvre, V., Donnadieu, Y., Goddéris, Y., Fluteau, F., and HubertThéou, L.: Was the Antarctic glaciation delayed by a high degassing rate during the early Cenozoic?, Earth Planet. Sci. Lett., 371-372, 203-211, 2013.

Longinelli, A. and Nuti, S.: Revisited phosphate-water isotopic temperature scale, Earth Planet. Sci. Lett., 19, 373-376, 1973. 
Louise Chilvers, B., Delean, S., Gales, N. J., Holley, D. K., Lawler, I. R., Marsh, H., and Preen, A. R.: Diving behaviour of dugongs, Dugong dugon, J. Exp. Mar. Biol. Ecol., 304, 203-224, 2004.

Machel, H. G., Mason, R. A., Mariano, A. N., and Mucci, A.: Causes and emission of luminescence in calcite and dolomite, in: Luminescence microscopy and spectroscopy: qualitative and quantitative applications, edited by: Barker, C. E. and Kopp, O. C., SEPM Short, Tulsa, Oklahoma, USA, 25, 9-173, 1991.

Major, R. P.: Cathodoluminescence in post-Miocene carbonates, in: Luminescence microscopy and spectroscopy: qualitative and quantitative applications, edited by: Barker, C. E. and Kopp, O. C., SEPM Short, Tulsa, Oklahoma, USA, 25, 149-155, 1991.

Marshall, J., Kushnir, Y., Battisti, D., Chang, P., Czaja, A., Dickson, R., Hurrell, J. W., McCartney, M., Saravanan, R., and Visbeck, M.: North Atlantic climate variability: phenomena, impacts and mechanisms, Int. J. Climatol., 21, 1863-1898, 2001.

Martini, E.: Bestandsaufnahme des Nannoplankton im "präaquitanen" Tertiär des Mainzer Beckens, Mainzer geowissenschaftliche Mitteilungen, 10, 29-36, 1982 (in German).

Martini, E. and Müller, C.: Das marine Alttertiär in Deutschland und seine Einordnung in die Standard Nannoplankton Zonen, Erdöl und Kohle, 24, 381-384, 1971 (in German).

Miller, K. G., Kominz, M. A., Browning, J. V, Wright, J. D., Mountain, G. S., Katz, M. E., Sugarman, P. J., Cramer, B. S., ChristieBlick, N., and Pekar, S. F.: The Phanerozoic record of global sea-level change, Science, 310, 1293-1298, 2005.

Mosbrugger, V., Utescher, T., and Dilcher, D. L.: Cenozoic continental climatic evolution of Central Europe, Proc. Natl. Acad. Sci. USA, 102, 14964-14969, 2005.

O’Neil, J. R., Roe, L. J., Reinhard, E., and Blakes, R. E.: A rapid and precise method of oxygen isotope analysis of biogenic phosphate, Israel J. Earth Sci., 43, 203-212, 1994.

Ottersen, G., Planque, B., Belgrano, A., Post, E., Reid, P., and Stenseth, N.: Ecological effects of the North Atlantic Oscillation, Oecologia, 128, 1-14, 2001.

Paillard, D., Labeyrie, L., and Yiou, P.: Macintosh program performs time-series analysis, Eos Transaction of the American Geophysical Union, 77, 379-379, 1996.

Pälike, H., Norris, R. D., Herrle, J. O., Wilson, P. A., Coxall, H. K., Lear, C. H., Shackleton, N. J., Tripati, A. K., and Wade, B. S.: The heartbeat of the Oligocene climate system, Science, 314, 1894-1898, 2006.

Peharda, M., Crnčević, M., Bušelić, I., Richardson, C. A., and Ezgeta-Balic, D.: Growth and longevity of Glycymeris nummaria (Linnaeus, 1758) from the eastern Adriatic, Croatia, J. Shellfish Res., 31, 947-950, 2012.

Pellegrini, M., Lee-Thorp, J. A., and Donahue, R. E.: Exploring the variation of the $\delta^{18} \mathrm{O}_{\mathrm{p}}$ and $\delta^{18} \mathrm{O}_{\mathrm{c}}$ relationship in enamel increments, Palaeogeogr. Palaeocl., 310, 71-83, 2011.

Picot, L.: Le Paléogène des synclinaux du Jura et de la bordure sudrhénane: Paléontologie (Ostracodes), paléoécologie, biostratigraphie, paléogéographie, GeoFocus, 5, 1-240, 2002 (in French).

Pross, J.: Aquatische Palynomorphe im Rupel des Mainzer Beckens (Oligozän, Südwestdeutschland): Paläoökologie, Biostratigraphie und Taxonomie, Tübinger Mikropaläontologische Mitteilungen, 15, 1-181, 1997 (in German).

Pross, J.: Paleo-oxygenation in Tertiary epeiric seas: evidence from dinoflagellate cysts, Palaeogeogr. Palaeocl., 166, 369-381, 2001.
Pross, J. and Schmiedl, G.: Early Oligocene dinoflagellate cysts from the Upper Rhine Graben (SW Germany): paleoenvironmental and paleoclimatic implications, Mar. Micropaleontol., 45, 124, 2002.

Pross, J., Bruch, A., and Kvaček, Z.: Paläoklima-Rekonstruktionen für den Mittleren Rupelton (Unter-Oligozän) des Mainzer Beckens auf der Basis mikro-und makrobotanischer Befunde, Mainzer Geowissenschafliche Mitteilungen, 27, 79-92, 1998 (in German).

Pross, J., Bruch, A. A., Mosbrugger, V., and Kvacek, Z.: Paleogene pollen and spores as a tool for quantitative paleoclimate reconstructions: the Rupelian (Oligocene) of Central Europe, in: Proceedings of the Ninth International Palynological Congress, edited by: Goodman, D. K. and Clarke, R. T., Houston, Texas, USA, 1996, 23-28 June 1996, American Association of Stratigraphic Palynologists Foundation, 299-310, 2000.

Putnis, A. and Putnis, C. V.: The mechanism of reequilibration of solids in the presence of a fluid phase, J. Solid State Chem., 180, 1783-1786, 2007.

Ramsay, K., Kaiser, M. J., Richardson, C. A., Veale, L. O., and Brand, A. R.: Can shell scars on dog cockles (Glycymeris glycymeris L.) be used as an indicator of fishing disturbance?, J. Sea Res., 43, 167-176, 2000.

Raper, S. C. B. and Braithwaite, R. J.: Low sea level rise projections from mountain glaciers and icecaps under global warming, Nature, 439, 311-313, 2006.

Ritzkowski, S.: Das Tertiär der Hessischen Senke in der Stratigraphischen Tabelle von Deutschland 2002, Newsl. Stratigr., 41, 339-346, 2005.

Rombouts, I., Beaugrand, G., and Dauvin, J.-C.: Potential changes in benthic macrofaunal distributions from the English Channel simulated under climate change scenarios, Estuar. Coast. Shelf Sci., 99, 153-161, 2012.

Ropes, J. W.: Modern methods used to age oceanic bivalves, Nautilus, 99, 53-57, 1985.

Royer, C., Thébault, J., Chauvaud, L., and Olivier, F.: Structural analysis and paleoenvironmental potential of dog cockle shells (Glycymeris glycymeris) in Brittany, northwest France, Palaeogeogr. Palaeocl., 373, 123-132, 2013.

Sato, S.: Spawning periodicity and shell microgrowth patterns of the venerid bivalve Phacosoma japonicum (Reeve, 1850), Veliger, 38, 61-72, 1995.

Schindler, T., Poschmann, M., and Wuttke, M.: Chondrichthyan feeding depressions in a subtidal coastal environment from the Mainz Basin (Oligocene, SW Germany), N. Jb. Geol. Paläont. Abh., 237, 29-39, 2005.

Schöne, B. R. and Fiebig, J.: Seasonality in the North Sea during the Allerød and Late Medieval Climate Optimum using bivalve sclerochronology, Int. J. Earth Sci., 98, 83-98, 2008.

Schöne, B. R., Goodwin, D. H., Flessa, K. W., Dettman, D. L., and Roopnarine, P. D.: Sclerochronology and growth of the bivalve mollusks Chione (Chionista) fluctifraga and C. (Chionista) cortezi in the northern Gulf of California, Mexico, Veliger, 45, 45-54, 2002.

Schöne, B. R., Freyre Castro, A. D., Fiebig, J., Houk, S. D., Oschmann, W., and Kröncke, I.: Sea surface water temperatures over the period 1884-1983 reconstructed from oxygen isotope ratios of a bivalve mollusk shell (Arctica islandica, southern North Sea), Palaeogeogr. Palaeocl., 212, 215-232, 2004. 
Schöne, B. R., Dunca, E., Fiebig, J., and Pfeiffer, M.: Mutvei's solution: An ideal agent for resolving microgrowth structures of biogenic carbonates, Palaeogeogr. Palaeocl., 228, 149-166, 2005a.

Schöne, B. R., Houk, S. D., Freyre Castro, A. D., Fiebig, J., Oschmann, W., Kroncke, I., Dreyer, W., and Gosselck, F.: Daily growth rates in shells of Arctica islandica: assessing subseasonal environmental controls on a long-lived bivalve mollusk, Palaios, 20, 78-92, 2005b.

Sissingh, W.: Tertiary paleogeographic and tectonostratigraphic evolution of the Rhenish Triple Junction, Palaeogeogr. Palaeocl., 196, 229-263, 2003.

Solomon, S., Qin, D., Manning, M., Chen, Z., Marquis, M., Averyt, K. B., Tignor, M., and Miller, H. L. (Eds.): Contribution of Working Group I to the Fourth Assessment Report of the Intergovernmental Panel on Climate Change, 2007, Cambridge University Press, Cambridge, UK and New York, NY, USA, 996 pp., 2007.

Spiegel, C., Kuhlemann, J., and Frisch, W.: Tracing sediment pathways by zircon fission track analysis: Oligocene marine connections in Central Europe, Int. J. Earth Sci., 96, 363-374, 2007.

Stenseth, N. C., Mysterud, A., Ottersen, G., Hurrell, J. W., Chan, K.-S., and Lima, M.: Ecological effects of climate fluctuations, Science, 297, 1292-1296, 2002.

Strom, A., Francis, R. C., Mantua, N. j, Miles, E. L., and Peterson, D. L.: North Pacific climate recorded in growth rings of geoduck clams: A new tool for paleoenvironmental reconstruction, Geophys. Res. Lett., 31, L06206, doi:10.1029/2004GL019440, 2004.

Taylor, J. D. and Layman, M.: The mechanical properties of bivalve (Mollusca) shell structures, Palaeontol., 15, 73-87, 1972.

Thewissen, J. G. M., Cooper, L. N., Clementz, M. T., Bajpai, S., and Tiwari, B. N.: Whales originated from aquatic artiodactyls in the Eocene epoch of India, Nature, 450, 1190-1194, 2007.

Thomas, R. D. K.: Functional morphology, ecology, and evolutionary conservatism in the Glycymerididae (Bivalvia), Palaeontol., $18,217-254,1975$.
Thomas, R. D. K.: Shell form and the ecological range of living and extinct Arcoida, Paleobiol., 4, 181-194, 1978.

Tsuboi, C. and Hirata, M.: Arrangement of micro-crystals of calcium carbonate in some fossil shells, Glycymeris yessoensis SOWERBY, B. Earthq. Res. I. Tokyo, 13, 660-664, 1935.

Tütken, T.: Die Bedeutung der Knochenfrühdiagenese für die Erhaltungsfähigkeit in vivo erworbener Element- und Isotopenzusammensetzungen in fossilen Knochen, Doctoral Thesis, EberhardKarls-Universität Tübingen, Germany, 331 pp., 2003 (in German).

Tütken, T., Vennemann, T. W., Janz, H., and Heizmann, E. P. J.: Palaeoenvironment and palaeoclimate of the Middle Miocene lake in the Steinheim basin, SW Germany: a reconstruction from $\mathrm{C}, \mathrm{O}$, and $\mathrm{Sr}$ isotopes of fossil remains, Palaeogeogr. Palaeocl., 241, 457-491, 2006.

Vellinga, M. and Wood, R. A.: Global climatic impact of a collapse of the Atlantic thermohaline circulation, Climatic Changes, 54, 251-267, 2002.

Vennemann, T. W., Fricke, H. C., Blake, R. E., Neil, J. R. O., and Colman, A.: Oxygen isotope analysis of phosphates: a comparison of techniques for analysis of $\mathrm{Ag}_{3} \mathrm{PO}_{4}$, Chem. Geol., 185, 321-336, 2002.

Waller, T. R.: Scanning electron microscopy of shell and mantle in the order Arcoida (Mollusca: Bivalvia), Smithsonian Contributions to Zoology, 313, 1-58, 1980.

Wanamaker, A. D., Kreutz, K. J., Schöne, B. R., and Introne, D. S.: Gulf of Maine shells reveal changes in seawater temperature seasonality during the edieval limate nomaly and the Little Ice Age, Palaeogeogr. Palaeocl., 302, 43-51, 2011.

Zachos, J. C., Dickens, G. R., and Zeebe, R. E.: An early Cenozoic perspective on greenhouse warming and carbon-cycle dynamics. Nature, 451, 279-283, 2008. 